\title{
Je možné vyriešit' spor realizmu a konštruktivizmu?
}

\author{
Rastislav Kostolný \\ Filozofická fakulta \\ Katolícka univerzita v Ružomberku \\ Hrabovská cesta 1B, 03401 Ružomberok \\ r.kostolny@gmail.com
}

Ciel'om textu je nadviazat’ na diskusiu o spore realizmu a konštruktivizmu, ktorá prebehla medzi Jaroslavom Peregrinom a Tomášom Marvanom na stránkach časopisu Filosofie dnes. Samotná diskusia vznikla ako reakcia na Marvanom publikovanú knihu Realismus a relativismus. Marvan v nej zastáva špecifické stanovisko realizmu, z ktorého vedie kritiku relativizujúcich postojov. Peregrin tvrdí, že spor nie je možné riešit,, lebo obe súperiace strany sú v konečnom dôsledku nevyvrátitelné a argumenty pre a proti sa držia v patovej situácii. Marvan tvrdí, že spor je možné riešit’ v prospech realizmu. Predkladaný text sa voči obom názorom vymedzuje a predstavuje návrh ako daný spor riešit. Riešenie spočíva $\mathrm{v}$ rozpustení samotného sporu a v predstavení hybridnej koncepcie, ktorá problémy realizmu a konštruktivizmu prekonáva. Text je rozdelený na tri časti, v prvej je uvedená kritika Marvanom zastávaného realizmu, v druhej časti je predstavená stručná analýza zdroju sporu a v záverečnej časti je načrtnutá koncepcia, ktorá spor prekonáva.

Klúčové slová: realizmus, relativizmus, konštruktivizmus, veda, spor 


\section{Úvod}

V roku 2014 Tomáš Marvan publikoval knihu Realismus a relativismus ${ }^{1}$, v ktorej sa obsiahlo venuje analýze stanovísk autorov, ako sú Quine, Davidson, Putnam, Goodman a Rorty. Marvan vedie túto analýzu $\mathrm{z}$ hl'adiska špecifickej verzie realizmu (d’alej len $\mathrm{R}_{\mathrm{M}}{ }^{2}$ ). Ďalej uvádza, že argumentácia rozoberaných autorov nedokáže ohrozit ním zastávaný realizmus $\mathrm{R}_{\mathrm{M}}$, ked’že tieto koncepcie vedú $\mathrm{k}$ neprijatel'ným, či neudržatel'ným dôsledkom. ${ }^{3} \mathrm{~V}$ knihe je teda možné nájst' nielen kritiku spomenutých autorov, ale aj obhajobu $\mathrm{R}_{\mathrm{M}}$. Táto publikácia vyvolala kritickú reakciu u Jaroslava Peregrina, ktorý na stránkach časopisu Filosofie dnes zhrnul svoje pripomienky do článku s názvom Realismus, relativismu a trápení duch ${ }^{4}$. Tento článok bol nasledovaný d’alšími reakciami, kde Marvan ${ }^{5}$ a Peregrin ${ }^{6}$ pokračovaliv argumentácii. ${ }^{7}$ Samotná kniha spolu s nasledujúcou diskusiou prinášajú mnoho zaujímavých myšlienok a podnetných názorov. Stanoviská, ktoré sú v danej diskusii zastávané, je možné zhrnút nasledovne;

Marvan tvrdí, že A) realizmus (d’alej len (R)) je obhájitel'ný koncept, ktorý nevyústi $\mathrm{v}$ absurdné alebo neprijatel'né dôsledky. Zatial' čo konštruktivizmus (d'alej len (K)) vyžaduje podl'a Marvana prijat' neudržatel'né ontologické záväzky. B) Preto je spor (R) a (K) riešitel'ný.

Peregrin tvrdí, že A) existuje mnoho argumentov, ktoré nahrávajú (R) či (K), no rovnako mnoho argumentov, ktoré im odporujú. ${ }^{8}$

1 Napriek tomu, že názov knihy hovorí o relativizme, v texte Marvan použiva termín konštruktivizmus ako súhrnné pomenovanie koncepcií pripisujúcich pôvod štruktúry sveta človeku. Preto budem v texte hovorit’ o spore realizmu a konštruktivizmu. Pozri Marvan (2014, S. 12-14).

2 Pre jednoduchšiu identifikáciu zavádzam $\mathrm{R}_{\mathrm{M}}$ ako skratku pre realizmus Marvanovskeho typu. Potom skratky (R) a (K) predstavujú všeobecnejšie kategórie, teda realizmus a konštruktivizmus vo všeobecnosti.

3 Pozri Marvan (2014, s. 14-15).

4 Peregrin (2014).

5 Marvan (2015).

6 Peregrin (2016).

7 Na diskusiu reagoval aj Martin Zach svojím článkom Vědecký realismus jako kultivace ducha. Zach (2017), na ktorý potom odpovedal Peregrin v článku Trápení může být kultivací. Ale přestává tak být trápením? Peregrin (2017).

8 Explicitne hovorí o tom, že obe stanoviská sa dajú naformulovat tak, že je takmer nemožné ich vyvrátit', no to neznamená, že sú tým potvrdené. Porovnaj Peregrin (2014, s. 72-73) a Peregrin (2016, s. 126-127). 
Tento spor ilustruje ako bezútešný stav, kde sa súperi navzájom držia v bezvýchodiskovej situácií. Pomenúva ju anglickým deadlock, teda akýsi smrtel'ný kŕč. B) Preto je spor (R) a (K) neriešitel'ný, je to trápenie ducha. Treba ho opustit’ a venovat sa iným otázkam. ${ }^{9}$

Na túto diskusiu chcem nadviazat’ tým, že sa pokúsim vymedzit’ voči obom názorom a ponúknem alternatívne stanovisko. S Marvanom nesúhlasím $\mathrm{v}$ bode $\mathrm{A}$ ), no súhlasím $\mathrm{s}$ ním $\mathrm{v}$ bode $\mathrm{B}$ ). Teda, nesúhlasím $\mathrm{s}$ tým, že $\mathrm{R}_{\mathrm{M}}$ je udržatel'ný, no súhlasím s tým, že spor $(\mathrm{R}) \mathrm{a}(\mathrm{K})$ je riešitel'ný. Avšak riešenie, ktoré obhajujem ja, sa odlišuje od toho, ktoré predkladá Marvan. Smer, akým sa dá zo sporu dostat', je naznačený v Peregrinovom tvrdení A). Teda, s Peregrinom súhlasím v tom, že sa argumentácia v prospech jedného, či druhého stanoviska dostáva do slepej uličky. No nesúhlasím s tým, že by sme mali kvôli tomu túto diskusiu opustit. Čo navrhujem ja, je tento spor rozpustit’ a ukázat', že zastávat' vyhranený (R) alebo (K) je neúplné a redukujúce. Obe stanoviská sú v niečom platné a v niečom nie, preto sa zdá byt' vhodné ich skombinovat'.

Navrhujem teda riešenie rozpustením..$^{10}$ To chcem dosiahnut tak, že sa pokúsim ukázat', v čom spočíva zdroj rozoberaného sporu. Hlavnou inšpiráciou je v tomto prípade text Pavla Labudu s názvom Priamočiary realizmus a jeho pozícia $v$ rámci sporu realizmu a antirealizmu ${ }^{11}$. Tu Labuda predstavuje zaujímavú myšlienku o podstate tohto sporu. Ukazuje, že realistické prístupy dávajú vel'ký dôraz na zdroj rozlišovania štruktúry vo svete, zatial’ čo antirealistické zdôrazňujú proces tohto rozlišovania. $Z$ oblasti dišpút o vedeckom realizme sa ukazuje, že d’alší z možných zdrojov sporu (R) a (K) sú rôzne diskutované argumenty všeobecne nazývané pesimistická metaindukcia (d’alej len PMI) a argument žiadnych zázrakov (d’alej len NMA). ${ }^{12}$ Za predpokladu, že tieto

9 Porovnaj Peregrin (2014, s. 73) a Peregrin (2016, s. 127).

10 V anglosaskej literatúre sa s obl’ubou používa výraz „solving by dissolving“.

11 Labuda (2013).

12 Skratky PMI a NMA sú odvodené od slovných spojení použivaných v anglofónnom prostredí. $\mathrm{V}$ prvom prípade ide o „pessimistic meta induction“ a v druhom „no miracles argument“. Pre potreby tohto textu budem dané argumenty považovat’ za odôvodnené, napriek tomu, že existujú viaceré texty, ktoré odôvodnenost’ týchto argumentov problematizujú. $\mathrm{K}$ tomu viac napr. v Hoyningen-Huene (2018), alebo Forbes (2018). Taktiež je dôležité pripomenút, že tieto argumenty sa vylučujú, teda bud' platí jeden, alebo druhý. K tomu sa vyjadrím v záverečných častiach práce, kde ukazujem ako $\mathrm{IR}_{\mathrm{K}}$ tento vylučujúci charakter neutralizuje. 
zdroje identifikujem správne, riešenie sporu bude spočívat’ v hybridnej koncepcii, ktorá akcentuje aj zdroj aj proces rozlišovania a rovnako sa dokáže vyrovnat’ s oboma uvedenými argumentami. Za takúto koncepciu považujem inštrumentálny realizmus Ladislava Kvasza (d’alej len $\mathrm{IR}_{\mathrm{K}}$ ). Napriek tomu, že Kvasz buduje $\mathrm{IR}_{\mathrm{K}}$ hlavne ako pozíciu v otázke povahy matematiky a fyziky, dotýka sa tém, ktoré tieto dve disciplíny presahujú. Hlásim sa teda $k \mathrm{IR}_{\mathrm{K}}$ a $\mathrm{v}$ tomto texte sa snažím predstavit' $\mathrm{IR}_{\mathrm{K}}$ ako efektívnu stratégiu riešenia sporu $(\mathrm{R})$ a $(\mathrm{K})$.

Text rozdel'ujem do troch hlavných častí. $\mathrm{V}$ prvej sa pokúsim rekonštruovat' Marvanove stanovisko $\mathrm{s}$ dôrazom na body, ktoré považujem za klúčové a následne predstavím moju kritiku $\mathrm{R}_{\mathrm{M}}$. V druhej časti nadviažem na kritiku a predstavím analýzu zdrojov sporu. Tretia čast potom vychádza z výsledkov prvej a druhej, kde uvádzam jednotlivé prvky $\mathrm{IR}_{\mathrm{K}}$ ako efektívne stratégie riešiacej spor $(\mathrm{R})$ a $(\mathrm{K})$.

Mojím ciel’om je tak dokázat', že spor má riešenie vo forme hybridného stanoviska. Čiastkovými ciel'mi potom sú:

1. Dokázat', že RM je neudržatel'ný.

2. Ukázat', že argumentácia v prospech vyhranených stanovísk (R) a (K)vedie do slepej uličky.

3. Ukázat', že zdroj sporu je spor o akcent a konflikt PMI a NMA.

4. Ukázat', že IRK akcentuje aj zdroj aj proces rozlišovania a dokáže neutralizovat' vylučujúci charakter PMI a NMA, teda predstavuje hybridné stanovisko rozpúštajúce spor.

\section{Marvanov realizmus}

Marvan hned’ na úvod poskytuje niečo, čo by sa dalo nazvat’ minimálna definícia filozofického realizmu. (R) predstavuje presvedčenie, že materiálny svet existuje nezávisle na nás, našich mysliach, či našich teóriách. Teda svet je, aký je, či už l'udia existujú alebo nie. ${ }^{13}$ Takto vymedzený (R) však dokáže pod seba zahrnút aj taký pojem reality ${ }^{14}$, ktorý by mnoho realistov striktne odmietlo. Napr. nepoznatel'ná Kantova

13 Porovnaj Marvan (2014, s. 11).

14 Termíny „svet“ a „realita“ používam v texte ako synonymá, striedam ich čisto zo štylistických dôvodov. 
vec o sebe by pod túto minimálnu definíciu (R) spadala rovnako, ako tvrdenie, že tu existuje „niečo“, čo je na nás nezávislé. Myslím však, že takáto forma (R) nie je to, o čo realistom ide.

Marvan preto chce zastávat' konkrétnejšie vymedzený (R), pracovne ho môžem nazvat' (R) Devittovského typu (d’alej $R_{D}$ ), ked’že sa v jeho charakterizovaní opiera práve o slová Michaela Devitta. Takto vymedzený (R) predstavuje presvedčenie, že veci, na ktoré referujeme jazykom, ako tráva, jablko, pes, železo, existujú nezávisle na našej alebo kohokolvek mysli. No tento typ (R) nezostáva len pri veciach bežnej skúsenosti, ale zaväzuje sa k nezávislej existencii aj takých vecí, ako sú vedou postulované entity, protóny, kvarky a zakrivený časopriestor. ${ }^{15}$ $\mathrm{R}_{\mathrm{M}}$ teda predstavuje presvedčenie nie len o existencii nezávislej reality, ale o existencii nezávislej inherentne štruktúrovanej reality. Artefakty l’udskej tvorby sú s týmto realizmom kompatibilné napriek tomu, že ich podoba, vlastnosti a účel sú závislé na človeku, jeho mysli. Kompatibilné sú v tom, že všetky ich fyzikálne vlastnosti sú nezávislé a prislúchajú inherentnej štruktúre sveta. ${ }^{16}$

Za dôležité pri charakterizácii $\mathrm{R}_{\mathrm{M}}$ považujem úlohu teórie pravdy. Marvan tvrdí, že $R_{M}$ je hlavne téza o povahe reality, pričom špecifická teória pravdy zohráva pre (R) podružný problém. Nasleduje tak Devittov príklad a hovorí, že $\mathrm{R}_{\mathrm{M}}$ neberie na seba nerozumné záväzky tým, že by sa prihlásil k nejakej špecifickej teórii pravdy. Vyvrátenie, či potvrdenie nejakej teórie pravdy tak nemôže $\mathrm{R}_{\mathrm{M}}$ ohrozitł. Teda, $\mathrm{R}_{\mathrm{M}}$ sa nevystavuje problematickým, či neistým záväzkom. ${ }^{17}$

Ďalším podstatným prvkom pre $\mathrm{R}_{\mathrm{M}}$ je prihlásenie sa $\mathrm{k}$ niečomu, čo Marvan nazýva jeden správny opis (d’alej len $\mathrm{JSP}^{18}$ ). Táto predstava v princípe vychádza $\mathrm{z}$ vyššie spomenutého presvedčenia, že svet je nezávisle a inherentne štruktúrovaný a práve táto štruktúra je to, čo determinuje naše vnímanie sveta. Potom, ak je to pravda, tak musí podl'a Marvana existovat' JSP sveta, teda jeho štruktúry. Marvanovými slovami:

\footnotetext{
15 Porovnaj Marvan (2014, s. 12).

16 Pozri tamže, s. 12.

17 Pozri tamže, s. 13.

18 JSP je skratkou pre české ,jeden správný popis“, používam ju v rovnakej forme ako Marvan pre jednoduchšie identifikovanie pri porovnávaní textov.
} 
„Fyzický svět nám - metaforicky řečeno - vnucuje způsob, jímž ho máme popisovat. To neznamená ř́lkat, že správny popis „čeká tam venku“ na to, až ho odhalíme. Jazykové a jiné popisy jsou produkty, které neexistovaly dřív, než existovali lidé. Tyto popisy však svět nevytvářejí a pokud jsou správné, nepřipouštějí alternativy." ${ }^{19}$

JSP však netreba chápat’ ako jednu teóriu opisujúcu všetko. Marvan pripúšta varietu rôznych teórií, ktoré však musia byt' koherentne prepojitel'né. ${ }^{20}$ Podobným spôsobom oddel'uje JSP od nároku celistvosti, ked' hovorí, že nie je nutné chápat' JSP tak, že by nám mal podat' hotový, kompletný a celý opis sveta. Tvrdí:

„Př́ičetný realista naproti tomu bude tvrdit, že jsme vždy schopní předložit jen fragment JSP.“"21

Posledný aspekt $\mathrm{R}_{\mathrm{M}}$, na ktorý chcem upozornit’, je Marvanove tvrdenie, že sme schopní dosiahnut' objektívneho pohl'adu na vec. Do určitej miery táto predstava priamo vyplýva z prihlásenia sa k JSP. Ved', čo iného by malo byt’ JSP, ak nie objektívny pohl'ad na vec. Marvan to špecifikuje nasledovne:

„Lidé jsou s to dospět k pohledu na věc, který je objektivní ve smyslu postupného oproštění se od jakékoli dílčí perspektivy." 22

Ako príklad používa vedecký opis fotosyntézy, ktorý nemá charakter jednotlivej perspektívy, ani perspektívy skupiny l'udí a nejde ani o opis zložený zo všetkých pohl’adov na fotosyntézu. Zdá sa tak, že veda dokáže svet uchopit’ akoby „odnikadial““, dokáže predstavit’ opis očistený od akejkol'vek perspektívy. No zároveň, to nie je opis z „božieho oka“, lebo

19 Marvan (2014, s. 117).

20 Porovnaj tamže, s. 118.

21 Tamže, s. 120.

22 Tamže, s. 124. 
vedec pri opise neodkladá určité pojmové schémy ani jazyk v ktorých sa dané schémy vyjadrujú. ${ }^{23}$

Záverom Marvanovho textu je snaha podporit’ $\mathrm{R}_{\mathrm{M}}$ dvoma nepriamymi dôkazmi. Prvý dôkaz sa snaží ukázat', že (R) je v zhode so súčasnou vedou. Hovorí:

„Realismus můžeme podpořit také tím, že ukážeme jeho hladkou slučitelnost s přesvědčením a teoriemi o světě, které se osvědčily a jsou široce přijímány ve vědecké komunitě i mimo ni.“"24

Toto tvrdenie v princípe podporuje ukázaním toho, ako sa vedecké teórie pretavujú do úspešných technologických vymožeností. Teda dôkazom pre podporenie (R) vo vede je to, že veci zostrojené podla vedy naozaj fungujú. Z toho je potom možné odvodit, že vedecké teórie „přesně mapují inherentní uspořádání př́rody“. ${ }^{25}$

Druhý nepriamy dôkaz pre podporenie $\mathrm{R}_{\mathrm{M}}$ je apel na „common sense“. $\mathrm{R}_{\mathrm{M}}$ je v súlade so zdravým rozumom a z pohl’adu zdravého rozumu je $\mathrm{R}_{\mathrm{M}}$ správnou ontologickou teóriou. ${ }^{26}$ Marvan si požičiava jeden špecifický princíp common sense od Thomasa Reida a hovorí, že pre realizmus je užitočné tento princíp zastávat'. Tento princíp v skratke hovorí, že to, čo jednoznačne a rozlíšene vnímame, existuje a existuje to tak, ako to vnímame. ${ }^{27}$ Marvan chce však tento princíp trochu modifikovat', aby viac zodpovedal súčasným vedeckým poznatkom, a preto tvrdí, že:

„Rozlišeně vnímané fyzické věci existují nezávisle na naší mysli a my se pomocí pozorování můžeme dopátrat jejich inherentních vlastností."28

23 Porovnaj tamže, s. 124.

24 Tamže, s. 127.

25 Tamže, s. 128.

26 Porovnaj tamže, s. 129.

27 Porovnaj tamže.

28 Tamže, s. 130. 
Aby som teda zhrnul $R_{M}$ do jednotnej podoby, tak na základe vyššie uvedených bodov je možné povedat', že definícia $\mathrm{R}_{\mathrm{M}}$ má dva aspekty, jeden je svojou povahou ontologický a druhý epistemický. Ontologický aspekt predstavuje presvedčenie o nezávislej a inherentne štruktúrovanej realite, kauzálne (z vonku) pôsobiacej na nás, naše zmysly a pozorovanie. Epistemický aspekt potom predstavuje presvedčenie, že veci, ktoré pozorujeme, či poznávame skrz naše zmysly a rovnako aj pomocou našich najlepších teórií, existujú a existujú tak, ako ich poznávame/vnímame. Potom $\mathrm{z}$ takto definovaného $\mathrm{R}_{\mathrm{M}}$ vyplýva, že musí existovat’ JSP reality. Implicitne sa tým hovorí, že existuje nám dostupný privilegovaný spôsob prístupu k realite.

\section{Kritika RM}

Na úvod mojej kritiky chcem formulovat’ nasledovnú generalizáciu ohl'adom stanoviska (K):

Príčetný konštruktivista nebude popierat’ existenciu na ňom nezávislého čohosi, čo nejakým spôsobom externe vplýva na jeho zmysly. ${ }^{29}$ Bude však tvrdit', že za realitu to môžeme považovat’ až po tom, ako to nejakým spôsobom uchopíme.

Myslím si, že táto generalizácia nie je problematická a dalo by sa predpokladat, že by s ňou súhlasila väčšina zainteresovaných. Ak by niekto túto generalizáciu odmietol a stále nástojčivo trval na tom, že svet je výlučným produktom jeho mysle, mal by nasledovat často používanú a oblúbenú radu mnohých odporcov (K), aby toto svoje presvedčenie dokázal napríklad skokom z okna svojej kancelárie na desiatom poschodí.

$\mathrm{R}_{\mathrm{M}}$, tak ako som ho charakterizoval v predchádzajúcej časti textu, túto generalizáciu d’aleko prekračuje a prihlasuje sa $\mathrm{k}$ nezávislej existencii inherentnej štruktúry sveta, ktorej súčastou sú predmety bežnej skúsenosti, ale aj entity našich najúspešnejších vedeckých teórií. Takúto formu (R) považuje za paradigmu realistickej pozície. ${ }^{30} \mathrm{~V}$ nasledujúcich kapitolách predstavím kritiku, v ktorej sa snažím ukázat', že $\mathrm{R}_{\mathrm{M}}$ tak, ako je obhajovaný v knihe Realismus a relativismus, je problematický.

29 Peregrin určitým spôsobom tvrdí to isté, pozri Peregrin (2014, s. 65).

30 Pozri Marvan (2014, s. 12). 


\subsection{Nejednoznačnost' RM}

Úvod knihy naznačuje, že v prípade $\mathrm{R}_{\mathrm{M}}$ pôjde hlavne o filozofický (R), teda koncepciu, ktorá chce $\mathrm{z}$ hladiska filozofie hovorit’ o skutočnosti. ${ }^{31}$ No už $\mathrm{v}$ predchádzajúcej časti sa ukázalo, že $\mathrm{R}_{\mathrm{M}}$ chce obhajovat' nezávislú existenciu vedou postulovaných entít. Čím sa prihlasuje aj $\mathrm{k}$ vedeckému ( $\mathrm{R})$. $\mathrm{Z}$ toho potom vyplýva, že $\mathrm{R}_{\mathrm{M}}$ pripisuje existenciu ako pozorovatel'ným veciam, tak aj nepozorovatel'ným entitám, ktoré opisujú niektoré z úspešných vedeckých teórií. Ako som to už spomínal v závere predchádzajúcej kapitoly, okrem toho, že $\mathrm{R}_{\mathrm{M}}$ je hlavne ontologickou tézou, prihlásenie sa $\mathrm{k}$ JSP poukazuje na to, že rozoberaná koncepcia má aj epistemický aspekt. Argumentácia v prospech $\mathrm{R}_{\mathrm{M}}$ uvedená v knihe sa však najviac venuje ontologickému aspektu, pričom ostatné sú len naznačené alebo predpokladané. To považujem za problematické, lebo takto široký záber $\mathrm{R}_{\mathrm{M}}$ je vystavený protiargumentom, či už zo strany filozofie vedy, prípadne vedcov samých, teórie poznania, ontológie a pod. Preto tvrdím, že $\mathrm{R}_{\mathrm{M}}$ je nejednoznačne vymedzený.

$\mathrm{K}$ tejto nejednoznačnosti prispieva aj spôsob argumentácie, ktorá je použivaná pri obhajobe a špecifikácii klúčových bodov $\mathrm{R}_{\mathrm{M}}$, ktoré som charakterizoval v predchádzajúcej kapitole. Najprv je predstavené vel'mi silné tvrdenie, ako je napr. presvedčenie o nezávislej existencii vecí každodennej skúsenosti a entít úspešných vedeckých teórií. Vzápätí je toto tvrdenie oslabené:

„Přesněji řečeno, většina těchto předmětů a látek existuje. Člověk je tvor omylný a jak vyjevuje pohled do historie, postulování některých předmětů bylo přehmatem.“"32

Túto vetu považujem za problematickú vzhl’adom na stanovisko, ktoré je v knihe zastávané. Ak má byt’ $\mathrm{R}_{\mathrm{M}}$ tézou o tom, že realita je taká, ako ju vnímame a poznávame, ako to, že sa niektoré naše teórie časom ukážu ako neplatné či problematické, napriek tomu, že v dobe, ked’ boli aktuálne predstavovali úspešné a odôvodnené presvedčenie? Čo bude

31 Pozri tamže, s. 11.

32 Tamže, s. 12. 
arbitrom, ktorý jednoznačne rozhodne, čo naozaj skutočne existuje a čo je len chybný či nedostatočný predpoklad? Ak ním má byt’ čas, a teda historický vývoj, tak napríklad geocentrizmus či presvedčenie o plochosti Zeme poukazujú na nestálost’ našich teórii.

Históriu a čas nemáme dostupnú v celku, aby sme dokázali s istotou rozhodnút' o platnosti našich teórií. Metaforicky povedané ${ }^{33}, \mathrm{R}_{\mathrm{M}}$ sa tak môže ocitnút’ v situácii podobnej piesku v presýpacích hodinách. Piesok v hornej časti predstavuje všetky tie teórie, vety, opisy a veci o ktorých je $\mathrm{R}_{\mathrm{M}}$ presvedčený, že nám verne prinášajú nezávislý svet. Dolná čast’ hodín predstavuje tie teórie, názory, obrazy a veci, ktoré sa časom ukázali, ako problematické či tažko udržatel'né. Môže sa nateraz zdat', že v hornej časti je dostatočné množstvo piesku na to, aby sa $\mathrm{R}_{\mathrm{M}}$ udržal a tých pár zrniečok, čo prepadlo, mu chýbat’ nebude. No s pribúdajúcim časom sa môže ocitnút’ v situácii, kedy hore nezostane nič. ${ }^{34}$

Zdá sa, že Marvan si túto možnost’ zmeny uvedomuje a tvrdí, že ontológie jednotlivých teórií sa časom menia, a preto treba predstavu jednej nadčasovej ontológie ${ }^{35}$ opustit. $\mathrm{R}_{\mathrm{M}}$ tak má určitým spôsobom provizórnu povahu. ${ }^{36}$ Táto provizórnost’ je však v napätí so základnou požiadavkou $\mathrm{R}_{\mathrm{M}}$, a to, byt viac, ako len triviálnym tvrdením o tom, že existuje „niečo“, čo je na nás nezávislé. Obávam sa, že ak máme brat’ $\mathrm{R}_{\mathrm{M}}$ vážne, teda $\mathrm{v}$ podobe, ako ho Marvan špecifikuje, ako tézu o povahe reality, tak snahou $\mathrm{R}_{\mathrm{M}}$ je práve určitý typ nadčasovej ontológie obhajovat. To sa ukazuje v tomto Marvanovom tvrdení:

„Je potom pravda, že realismus jako jakousi abstraktní možnost připouští i to, že svět, jak je sám o sebe, leží zcela mimo dosah našich pojmových schémat a i těch nejlepších

33 Táto metafora je z časti analogická PMI, ktoré chcem rozoberat’ v d’alšej časti textu.

34 Obávam sa, že nikto si nemôže byt’ úplne istý, či naše súčasné presvedčenia prežijú napr. tri tisíc rokov. Za predpokladu, že sa nám nejakým zázrakom nepodarí samých seba zničit, nedokážeme si ani len predstavit’ akými teóriami a presvedčeniami budú naši potomkovia o tisíce rokov disponovat. Napriek tomu, že ide o metaforu a špekuláciu, domnievam sa, že naša súčasná civilizácia môže v očiach kultúry roku pättisíc (v prípade vyššie spomenutého predpokladu o sebazničení) vyzerat' analogicky kultúre afrických kmeňov v porovnaní so súčasnostou.

$35 \mathrm{~V}$ tomto kontexte je treba nadčasovú ontológiu chápat', ako ontológiu, ktorá sa podstatným spôsobom nezmení, či nepreukáže ako neplatná, ani s pribúdajúcim časom, ani s pribúdajúcimi poznatkami.

36 Pozri Marvan (2014, s. 21). 
vědeckých teorií. Realista však nemá důvod se $\mathrm{k}$ této tezi upínat, pokud nemá $\mathrm{k}$ tak př́ísné skepsi pádné důvody. Např. já jsem ve své knize obhajoval verzi devittovského externího realismu, podle které se svět skládá právě z těch druhů předmětů, které (a) běžné pokládáme za jsoucí, nebo které (b) postulují nejlepší vědecké teorie (jež překonaly fázi pouze slibných hypotéz).“37

Tu sa znova ukazuje problematický spôsob argumentácie, ktorý som spomenul $\mathrm{v}$ úvode tejto kapitoly. Teda najskôr silné tvrdenie, že $\mathrm{R}_{\mathrm{M}}$ má provizórny charakter a pripúšta omyl vo vedeckých alebo každodenných presvedčeniach, no $\mathrm{v}$ princípe realista nemá dôvod $\mathrm{k}$ tak silnej skepse, takže táto provizórnost’ je len okrajová záležitost'. Ďalšia vec je, že si neviem dostatočne dobre predstavit, čo iné by malo motivovat $\mathrm{R}_{\mathrm{M}} \mathrm{ku}$ prijatiu skeptickej formy (R) uvedenej $\mathrm{v}$ prvej časti citátu, ak nie nemožnost̉ nadčasovej ontológie. Alebo povedané obrátene, predpoklad možnosti nadčasovej ontológie považujem za dôvod prečo je $\mathrm{R}_{\mathrm{M}}$ presvedčený, že predmety každodennej skúsenosti a entity našich najlepších vedeckých teórií prináležia inherentnej štruktúre reality. Toto moje tvrdenie vychádza $\mathrm{z}$ toho, že $\mathrm{z}$ argumentácie $\mathrm{v}$ prospech $\mathrm{R}_{\mathrm{M}}$ nie je úplne jasné aké očakávania máme od (R) vlastne mat'. Marvan formuluje $\mathrm{R}_{\mathrm{M}}$ ako tézu, ktorá jednoznačne prekračuje presvedčenie, že tu je „niečo“, čo nejakým spôsobom existuje nezávisle. To ukazuje na silnú verziu $\mathrm{R}_{\mathrm{M}}$, kde práve nadčasová ontológia bude mat' svoje platné miesto. No poukaz na to, že $\mathrm{R}_{\mathrm{M}}$ ma provizórnu povahu skôr naznačuje slabú verziu. $\mathrm{V}$ takom prípade je však $\mathrm{R}_{\mathrm{M}}$ do určitej miery relativizujúci a je skôr podobný stanoviskám autorov, ktorých sa Marvan snaží kritizovat'.

Ďalší problém s touto nejednoznačnostou je, že v prípade silnej verzie je $R_{M}$ nielen (R) filozofickým ale aj (R) vedeckým. Ak chce $R_{M}$ zastávat' existenciu entít najlepších vedeckých teórií, je viac menej odkázaný na to, ako sa bude veda vyvíjat'. Tu hrozí, že raz bude zastávat existenciu jednej veci, inokedy zas druhej. Za predpokladu, že rozumiem správne ambícii, s ktorou je $\mathrm{R}_{\mathrm{M}}$ formulovaný, chce jednoznačne zastávat’ existenciu konkrétnych entít prináležiacich konkrétnej inherentnej

37 Marvan (2015, s. 98). 
štruktúre skutočnosti. No túto ambíciu považujem za prisilnú vzhl'adom na to, že veda nám neprináša finálne odpovede a jej výskum ešte nedospel do finálnej podoby. ${ }^{38} \mathrm{~V}$ prípade slabej verzie môže dôjst' $k$ tomu, že $\mathrm{R}_{\mathrm{M}}$ bude silnou tézou len o existencii každodenných entít a nešpecifikovanej inherentnej štruktúry reality. No takáto verzia nielenže nenapíňa vyššie spomenutú ambíciu, ale je aj filozoficky triviálna. Ďalší problém nejednoznačnosti $\mathrm{R}_{\mathrm{M}}$ považujem za ešte závažnejší, preto mu venujem nasledujúcu kapitolu.

\subsection{RM a teória pravdy}

Ako som spomínal v úvode, Marvan pri špecifikovaní $\mathrm{R}_{\mathrm{M}}$ vychádza z realizmu M. Devitta. Pre tento typ (R) je podl'a Marvana podstatné to, že neberie na seba nerozumné záväzky. Jedným z takýchto záväzkov je napr. korešpondenčná teória pravdy (d’alej KTP). ${ }^{39}$ Teda naším teóriám, aby boli pravdivé a platné, presne zodpovedajú tie časti skutočnosti, o ktorých rozprávajú. Marvan však tvrdí, že pre realistov nie je potrebné sa ku KTP prihlasovat', podl'a neho to nie je logickým dôsledkom ich postoja. ${ }^{40}$ Tvrdí:

„Problém správné teorie pravdy je z hlediska hajitelnosti realismu celkem podružný. Realismus je teze o nezávislé existenci vnější reality. Teorie pravdy odpovídá na speciálnější otázku ohledně vztahu dvojí části reality: lidských jazykových projevu a toho, čeho se tyto projevy týkají. Teprve předpokládáme-li objektivně existující svět a člověka jako

\footnotetext{
38 K tomuto tvrdeniu je možné pripojit’ jednu pozoruhodnú anekdotu zo začiatkov kariéry známeho fyzika M. Plancka, ktorá naznačuje, že zastávat’ takto silné presvedčenia sa môže nakoniec ukázat’ ako predčasné. Planck sa na začiatku svojho štúdia fyziky na univerzite spýtal svojho profesora P. von Jollyho na jeho názor na túto oblast' vedy. Jolly zhrnul fyziku ako vysoko rozvinutú a skoro dospelú disciplínu, ktorá čoskoro dosiahne svoj vrchol, ako to spravila geometria pred cca dvesto rokmi a nezostane toho vel’a, čo by ešte stálo za skúmanie. Tento Jollyho názor nebol nijak výnimočný, vystihoval vtedajšie všeobecné naladenie v určitých kruhoch fyziky. Paradoxne bol to práve Planck a rôzne komentáre k jeho práci od Jollyho, ktoré prispeli k rozvoju a explózii nového odvetvia fyziky, ako sú rôzne variácie relativity či kvantová mechanika. K tomu viacej Wells 2016, s. 61-63.
}

39 Porovnaj Marvan (2014, s. 13).

40 Porovnaj tamže, s. 13. 
jeho nepatrnou součást, můžeme začít budovat teorii pravdy. A pokud se ukáže, že korespondenční teorii nelze rozumně vypracovat, nepřinese to př́mé ohrožení realismu. Realista se může obrátit k jinému typu teorie pravdy. V této knize se proto nebudu zabývat tím, jakou konkrétní teorii pravdy by měl realista hájit."41

Mojou úlohou nie je skúmat', či pre (R) vo všeobecnosti, alebo pre Devittov realizmus je KTP logickým dôsledkom zastávaného postoja. Chcem však ukázat', že argumentácia $\mathrm{v}$ prospech $\mathrm{R}_{\mathrm{M}}$, ktorú Marvan predkladá, implicitne stojí na platnosti KTP.

Už uvedený citát považujem za problematický. Akým spôsobom sa môže predpoklad stat' základom, na ktorom je možné budovat' špecifickú teóriu pravdy? Nie je to skôr tak, že predpoklad je treba najprv podložit’ argumentáciou, aby mohol následne fungovat’ ako odôvodnené tvrdenie, z ktorého budeme budovat' d'alšie špecifikácie daného konceptu? Predpoklad sám o sebe neobstojí a zostáva len predpokladom. Ak by aj vyššie spomenutý citát platil, spôsob akým sa vedie argumentácia proti relativizujúcim stanoviskám a $\mathrm{v}$ prospech $\mathrm{R}_{\mathrm{M}}$ sa príliš často odvoláva práve na korešpondenciu presvedčení so svetom. To sa ukazuje na viacerých miestach, z ktorých vyberám niektoré ako príklad.

V kapitole rozoberajúcej Quina hovorí Marvan o tom, ako naše pojmové aparáty klasifikujú veci a vyznačujú im hranice. Smer tejto klasifikácie je jednoznačný, nejde o náš produkt, ale o inherentnú vlastnost’ skutočnosti. A podla čoho zistíme, že je klasifikácia správna? Odpoved’ je jasná: „... samozřejmě je třeba dodat: pokud klasifikujeme správně; ne každá klasifikace odráží uspořádaní přírody.“42 Správnoste klasifikácie zaručuje to, že odráža skutočnost'.

V kapitole rozoberajúcej Davidsona, Marvan porovnáva davidsonovský umiernený (R) s klasickým (R). V prvom prípade platí, všetky klasifikácie reality, ku ktorým dospejeme na základe podobnosti, sú rovnako akceptovatel'né. Zatial' čo v prípade klasického (R), niektoré klasifikácie

41 Tamže, s. 13.

42 Tamže, s. 30. 
viac zodpovedajú „kíbom“ reality než iné. ${ }^{33}$ Čo je inak povedané: správnost” našich presvedčení zaručuje ich korešpondencia so skutočnostou.

V odpovedi na Peregrinovu kritiku prináša podobné odôvodnenie svojho presvedčenia, ked’ sa snaží ukázat’ rozhodujúci prvok, na základe ktorého je možné vysvetlit, prečo niektoré naše teórie sú funkčnejšie než iné. Tvrdí: „Tyto teorie fungují, protože odrážejí na nás nezávislou strukturu reality." "C4 Čo je zas a znova variácia na už spomenuté: správnoste zaručuje korešpondencia so svetom. V závere toho istého textu hovorí o tom, že v prípade, že chceme hovorit’ o nejakom tvarovaní, tak treba smer tohto tvarovania otočit a tvrdit:" „svět tvaruje člověka, včetně jeho poznávacích nástrojůn, $\mathrm{k}$ nimž patř̌i pojmy.“45 $\mathrm{Z}$ uvedeného sa zdá, že $\mathrm{v}$ prípade nášho jazyka, teórií a poznávania nemáme na výber, a ak sa nechceme mýlit’ musíme svet zrkadlit.

$\mathrm{Tu}$ sa znova ukazuje už spomenutá tendencia analyzovanej argumentácie, kde sa najskôr predstaví nejaký silný argument a potom sa v zapätí oslabí, či dokonca až poprie. $\mathrm{R}_{\mathrm{M}}$ nepotrebuje KTP, ale $\mathrm{v}$ podstate vždy, ked' je potrebné odôvodnit'v čom spočíva správnost či platnost' teórií, tak sa bez KTP nezaobíde. Navyše, KTP určitým spôsobom implicitne požaduje aj nadčasovú ontológiu, lebo ak majú byt’ naše teórie platné a správne, tak jednoducho musia realitu zrkadlit', a teda postihovat jedinú správnu a platnú ontológiu. $\mathrm{R}_{\mathrm{M}}$ teda na jednej strane nepotrebuje KTP a opúšta nadčasovú ontológiu, ale ak chceme vysvetlit prečo sú niektoré naše teórie funkčné a správne, tak sa bez KTP nezaobídeme a nadčasová ontológia je potom vlastne už len výsledok správnych a platných teórií. S uvedeným sa tak spája d’alšia vec, ak naše teórie zrkadlia realitu, tak sme schopní dospiet' k jednému správnemu opisu skutočnosti.

\subsection{Jeden správny opis}

Marvan v závere svojej knihy vysvetl'uje, čo považuje za jeden správny opis JSP, pritom tvrdí, že realista vjeho poňatí sa k takejto predstave bude hlásit. ${ }^{46}$ Sčasti som JSP charakterizoval už v prvej kapitole. Ide o koncept

43 Porovnaj tamže, s. 55.

44 Marvan (2015, s. 97).

45 Tamže, s. 102.

46 Pozri Marvan (2014, s. 117). 
stojaci na presvedčení o existencii externej inherentne štruktúrovanej reality, ktorá determinuje naše poznávanie. Takto charakterizovaná realita logicky vylučuje, aby sme ju opisovali inak než jedným spôsobom. Alebo inak povedané, samotná štruktúra reality vopred diskvalifikuje všetky opisy, ktoré jej nezodpovedajú. Marvanovými slovami: „Tyto popisy však svět nevytvářejí a pokud jsou správné, nepřipouštějí alternativy." 47

JSP ako koncept, ku ktorému sa $\mathrm{R}_{\mathrm{M}}$ hlási, považujem z viacerých hl'adísk za problematický. Viacero Marvanových tvrdení, ktoré som doposial' uviedol ${ }^{48}$, explicitne vyjadrujú myšlienku, že štruktúra sveta determinuje naše poznávanie a presvedčenia, teórie, koncepcie, ktoré v tomto poznávaní dostávame, sú pravdivé a platné jedine vtedy, ak s týmto svetom korešpondujú. JSP je potom len d’alšie vyjadrenie pre pravdivé, korešpondujúce, teórie či opisy. Teda to, že sme dosiahli JSP sa overuje jednoznačnou korešpondenciou našich opisov so skutočnostou. Ak je však JSP možný, tak je možné dosiahnut’ aj súhrnnú náuku o tom, čo skutočne existuje. Inak povedané môžeme dosiahnut' to, čo som pri výklade $\mathrm{R}_{\mathrm{M}}$ nazval nadčasová ontológia. Tu však nastáva prvý problém. Ak má $\mathrm{R}_{\mathrm{M}}$ provizórny charakter, ak nechce dosiahnut nadčasovú ontológiu a neplatnost’ KTP ho nemôže principiálne ohrozit’, tak JSP nie je $\mathrm{s}_{\mathrm{M}}$ v súlade. Nezaviazat’ sa k nadčasovej ontológii a ku KTP, no považovat'JSP za princíp, ku ktorému by sa mal hlásit’ realista považujem za nekonzistentné. Bez nadčasovej ontológie chýba arbiter rozhodujúci o tom, že ide o ,jeden“ opis a bez KTP chýba arbiter pre to, aby šlo o „správny“ opis. Tu môže padnút’ námietka, že JSP začína slovom jeden a nie jediný, potom je moja kritika založená na neoprávnene silnom očakávaní od JSP. Avšak k takto silnému chápaniu JSP ma vedie práve spôsob akým je JSP charakterizovaný, ako opis, ktorý, ak je správny, tak nepripúšta alternatívy.

JSP je tak predstavený ako silný koncept, no ako som to ukazoval na viacerých miestach, spôsob argumentácie v prospech $\mathrm{R}_{\mathrm{M}}$ silné tvrdenia postupne oslabuje. Marvan pripúšta mnohost' rôznych správnych opisov, ktoré si zdá sa nekonkurujú. Jednoducho ide o opisy rôznych 
aspektov tej istej veci. Ak sa však niektoré opisy vylučujú, je potrebné sa ich vzdat' a vyhlásit’ za neplatné. Alebo ich zlúčit’ do vyššej teórie, schopnej ich zjednotit. ${ }^{49}$ Doposial' v tejto myšlienke problém nevzniká. Na makroskopickej úrovni máme bežne skúsenost’ s tým, že jednej veci zodpovedá viacero správnych opisov. Ťažkosti však nastávajú, ak sa presunieme do zložitejších častí vedy. Tu už nie je možné jednoznačne zlúčit’ napr. klasickú fyziku s kvantovou mechanikou. Do hry tu prichádza relativizujúca otázka: vzhl’adom na aký objekt, či vzhl'adom na akú situáciu platí prvé alebo druhé? Napríklad vo fyzike sa vyskytujú opisy, ktoré si zdanlivo odporujú ako je napr. nemožnost’ naraz zmerat’ rýchlost’ a polohu „objektov“ typu elektrón na úrovni subatomárnej fyziky a možnost’ súčasne merat’ polohu a rýchlost’ makroskopických objektov typu kameň na úrovni klasickej fyziky. Zaujímavé na tomto príklade je to, že objekty podliehajúce druhému opisu sa podl'a všetkého skladajú z „objektov“ podliehajúcim prvému opisu. Je možné pripustit, že tieto moje príklady by spadali pod varietu zlučitelných správnych opisov. No príklad, ktorý používa Marvan, považujem za mierne problematický.

Pre ilustráciu možnosti viacerých správnych opisov používa rôznost’ jednotiek pre vyjadrenie dížky či teploty. ${ }^{50}$ Je možné spýtat’ sa, čomu v realite zodpovedá napr. to, ked’ poviem, že vonku je 15 stupňov? Ak by som mal brat' $\mathrm{R}_{\mathrm{M}}$ úplne doslovne, tak $\mathrm{v}$ tejto vete vyjadrujem to, že vo svete je niečo, čo pocitujeme ako teplotu a je toho 15 . S tým, že by existovalo niečo, čo vnímame ako teplo a chlad nie je problém, ale čo vyjadruje tá číslovka? Naozaj je vo svete niečoho 15 a je tam toho tol'ko aj keby som neexistoval? A to, čoho je tam 15, determinuje to, že to môžem vôbec povedat?? Myslím si, že v tomto prípade Marvan nepoužil správny príklad, lebo ako v prípade teploty, tak v prípade dížky sa priamo ukazuje, akým spôsobom vkladáme do sveta štruktúru. Celziova stupnica predstavuje vcelku arbitrárne zvolené stupne reprezentujúce zdvih tepelného média, uzatvoreného v sklenenej trubici, po stupnici s l'ud’mi zvolenou škálou. Nulový bod je zvolený na stav, v ktorom sa voda vyskytuje vo všetkých troch štádiách (tepelné, plynné a kvapalné). Tým nechcem povedat', že by teplota neexistovala, existuje, avšak to, ako

49 Porovnaj tamže, s. 118.

50 Pozri tamže, s. 117. 
ju opíšeme, sa bude menit’ vzhl'adom na to, aký rámec zvolíme (pohyb elementárnych častíc, výsledok trenia, škála zvolená podl’a bodu, kedy ustáva pohyb častíc a pod.)

$\mathrm{V}$ prípade dížky je to ešte zjavnejšie, dížku môžeme merat’ napr. v stopách určených podl'a dížky chodila Anglického král'a, alebo si môžem zaumienit’ merat' dížku pomocou vel'mi nepraktickej fluidnej jednotky; tykadiel slimáka domáceho. Táto jednotka bude škálou od plných tykadiel po skryté tykadlá. Potom môžem povedat', že dížka klávesnice, na ktorej práve píšem, je 45 pst (plných slimačích tykadiel), čomu v realite bude zodpovedat číslovka 45? Čoho je tam 45, bolo by tam 45 pst aj keby som neexistoval? Tvrdenie, že moja klávesnica má 45 pst by som dokonca mohol overit’ tým, že by som zobral slimáka, počkal kým by sa jeho tykadlá plne narovnali a odmeral, či je tomu skutočne tak. Popísal som tým dokonca realitu a táto realita môjmu opisu zodpovedá. Nemyslím si však, že to podstatným spôsobom dokazuje JSP, ako súhrn variety viacerých opisov.

Tým sa znova vraciam k tomu, ako chápat’ slovo „jeden“ v JSP, a zdá sa, že ho netreba chápat’ doslovne. Marvan pripúšta, že by sme mohli opisy zoradit’ do tried, prípadne ich kategorizovat’ na základe presnosti. ${ }^{11}$ To by mohla byt' schodná cesta. Je predsa jasné, že bežný opis nášho každodenného života je menej presný ako ten vedecký, ale, ktorý bude správny, ked’ si budú protirečit’ prípadne budú rovnakú skutočnost' opisovat diametrálne odlišne? Ked' teraz sedím a píšem tento text, som podl'a všetkých mne dostupných evidencií v pokoji a okrem pohybu mojich prstov po klávesnici, či zdvíhajúceho sa hrudníku pri nádychoch, nevykonávam žiaden d’alší pohyb. Avšak z hl'adiska našej hviezdnej sústavy sa spolu so Zemou hýbem závratnou rýchlostou, niekol'ko tisíc kilometrov za hodinu, okolo slnka. Je prirodzené, že d’alšou deskripciou je možné oba vyššie uvedené opisy dat’ do súvisu. Predstavme si však, že zhodou okolností ešte nemáme nástroje na meranie rýchlostí astronomických telies, prípadne sme sa ešte nedostali do bodu, kedy by sme opustili geocentrickú predstavu. Čo by predstavovalo JSP v takomto prípade? A ešte podstatnejšia otázka, na základe čoho si môžeme byt istí, že naše súčasné a najlepšie teórie, 
ktorým by Marvan pripísal podobu JSP, nie sú v rovnakej situácii v akej bol geocentrizmus?

Zdá sa, že si Marvan túto možnost' uvedomuje. Preto d’alej oslabuje JSP a tvrdí, že absolútnost’ JSP nie je potrebná a dokonca priznáva, že takto chápaný JSP je l'udom nedosiahnutel'ný ideál. ${ }^{22}$ Priamo hovorí: „PY̌ričetný realista naproti tomu bude tvrdit, žejsme vždy schopni předložit jen fragment JSP." ${ }^{3}$ Obávam sa, že pri takto oslabenom JSP vlastne už z neho nič podstatné nezostáva. Nie je tak úplne jeden, dokonca nie je ani tak úplne správny, a jediné, čo nám zostáva, je opis. Ak mám len fragment nejakého celku, nakol'ko môžem z tohto fragmentu usudzovat' na celok alebo na jeho správnost'? Ak mám len jedného svedka nejakej udalosti, nakol'ko mám prijat jeho opis ako správny, ak je to ešte $\mathrm{k}$ tomu svedok, ktorý tú udalost' videl dajme tomu iba od polovice? V takejto podobe je koncept JSP triviálny a okrem toho, že funguje ako akýsi ideál, tak jeho prijatie či odmietnutie bude mat identický dôsledok, vždy dosiahneme iba fragment opisu.

JSP je tak problematický z viacerých hl’adísk. Prisilným chápaním slova „jeden“ sa zaväzujeme ku trvalej platnosti špecifického opisu, ktorý však vývojom vedy môže svoju platnost’ stratit. Tým sa aj vystavujeme riziku neschopnosti opodstatnit súčasnú platnost’ odporujúcich si platných opisov. V prípade slabého chápania ide vlastne o JSP v rámci jednej pojmovej schémy. No pojmové schémy sa môžu menit’ a jedna môže byt nahradená druhou, ktorá tú predchádzajúcu ukáže, ako úplne pomýlenú. Prečo potom vlastne hovorit’ o JSP, ked' máme iba opisy viazané na pojmové schémy? Takto oslabený JSP je však v napätí s Marvanovou kritikou konštruktivistického stanoviska, lebo práve (K) bude zdôrazňovat' platnost' opisov vzhl'adom na štruktúru konštituovanú $\mathrm{v}$ rôznych pojmových sietach. Viaceré tvrdenia $\mathrm{v}$ prospech $\mathrm{R}_{\mathrm{M}}$ však poukazujú skôr na silnejšie chápanie JSP, s čím sa spája aj špecifický pojem objektívnosti, ktorý Marvan rozoberá na posledných stránkach knihy.

52 Pozri tamže.

53 Tamže. 


\subsubsection{Pohl'ad bez perspektívy}

Marvan pod objektívnym pohladom nechápe ani pohl'ad božieho oka, ani pohl'ad zo všetkých perspektív, ale pohl'ad zbavený všetkých čiastočných perspektív. ${ }^{54}$ Takýto pohl'ad pripisuje modernej vede. Ako príklad používa fotosyntézu. ${ }^{55}$

Jednoduchý chemický vzorec fotosyntézy vyzerá asi takto:

$$
6 \mathrm{H}_{2} \mathrm{O}+6 \mathrm{CO}_{2} \rightarrow \mathrm{C}_{6} \mathrm{H}_{12} \mathrm{O}_{6}+6 \mathrm{O}_{2}
$$

Na prvý pohl’ad sa môže zdat', že ide o objektívny zápis, no treba si uvedomit’, že tento zápis je charakteristický pre chémiu. Jednotlivé symboly sú výsledkom špecifickej dohody l’udí, ktorí disciplínu chémie spolutvorili. Biológia by pristúpila $\mathrm{k}$ opisu fotosyntézy $\mathrm{z}$ hl'adiska funkcie chloroplastov a chlorofylu, ako organely rastlinnej bunky, ktorá zodpovedá za premenu anorganických látok, za pomoci slnečného žiarenia, na organické látky. Fyzikálna chémia by sa skôr pozerala na to, ako sa menia väzby medzi jednotlivými prvkami a ako preskakujú elektróny z orbitálov jedného atómu na druhý, atd'. Nakol'ko sú tieto deskripcie objektívne nedokážem posúdit, avšak tvrdit’, že ide o opisy bez perspektívy je problematické. Veda nie je niečo, čo tu existuje nezávisle na nás, je to prax l'udí, opisujúcich rôzne situácie a javy, pomocou l'ud’mi vytvorených nástrojov. Tieto nástroje sú vytvorené na to, aby našim holým zmyslom nedostupné veci sprostredkovali v nám zrozumitel'nej podobe. Tým však tvoria špecifické pohl'ady, ktoré na jednej strane odhal'ujú predtým nepoznané javy, no na strane druhej iné zahal'ujú. Chemický opis preferuje jednu čast’ javu, zatial' čo skúmanie subatomárnej fyziky sa pozerá na hlbšie štruktúry, vynechávajúc pritom makroskopické vlastnosti.

Potom hypotézy, ktoré sa preukázali ako úspešné môžeme považovat' za opisujúce skutočnost', avšak nejde o absolútne platné opisy bez perspektívy. Vždy ide o opis z perspektívy nejakej teórie, nejakého technického inštrumentária a nejakej hladiny presnosti. Veda neprináša

54 Porovnaj tamže, s. 120-124.

55 Porovnaj tamže, s. 124. 
jednoznačnú pravdu, ale aproximácie..$^{56}$ Potom, ak Marvan tvrdí, že chce obhajovat' verziu (R), ktorý sa bude zaväzovat' ku existencii ,... těch druhů předmětů, které (b) postulují nejlepší vědecké teorie (jež překonaly fázi pouze slibných hypotéz) “57, tak naše najlepšie vedecké teórie sú slubnými hypotézami. To, že sú niektoré natol'ko úspešné, že na základe nich dokážeme posielat l'udí na mesiac, či modifikovat genetickú výbavu živočíchov, nie je argumentom $\mathrm{v}$ prospech ich objektívnosti v zmysle pohladu bez perspektívy. Nie je vylúčené, že aj takto úspešné teórie nebudú prekonané inými.

Na základe uvedeného považujem nasledujúce tvrdenie za problematické. Marvan uvádza:

„Williams se zamýšlí nad tím, jak se za pomoci našich idiosynkratických pojmových a vnímacích aparátů dokážeme dobrat k popisu reality, který je na našich idiosynkratických schopnostech nezávislý. Takový popis objektivně reprezentuje poměry ve světě a na jeho detailech bychom se v principu mohli shodnout i s bytostmi, které by nesdílely naše poznávací zvláštnosti. “58

Problém vidím $\mathrm{v}$ tom, že zhoda vždy nastáva medzi nami a ako som už spomínal vyššie, naša veda je do značnej miery závislá na nás. Neviem si dostatočne dobre predstavit', ako by sme bytosti, ktorá nezdiel'a naše poznávacie zvláštnosti vysvetl'ovali napríklad vyššie uvedenú rovnicu fotosyntézy. Ak by táto bytost' dajme tomu nedokázala vnímat’ nič, čo presahuje úroveň subatomárnej „vel'kosti“ ${ }^{59}$, neboli by sme jej schopní

56 Samozrejme je možné povedat', že mnohé z toho, čo veda prináša je skutočnosti natol'ko blízke, že pre potreby vysvetl'ovania zákonitosti reality by bolo nanajvýš problematické hovorit' o aproximáciách. No z hl'adiska ciel'u textu a konceptu, ktorý chcem obhajovat' je táto myšlienka dôležitá. To sa ukazuje v záverečných častiach textu pri opise sprostredkovaného poznania a rozlišovacej schopnosti inštrumentov.

57 Marvan (2015, s. 98).

58 Marvan (2014, s. 124).

59 Tu by mohol niekto namietat', že som zámerne použil absurdnú predstavu bytosti, ktorá vníma iba subatomárny svet. Avšak, ked’ si uvedomíme, ako obmedzené je naše vnímanie, nepríde mi táto predstava až tak absurdná. Ako príklad je možné použit rozdiel nášho vnímania a vnímania živočíchov žijúcich pri morskom dne. Tu by zas mohla padnút námietka, že naše vnímanie je d'aleko dokonalejšie. $\mathrm{V}$ takom prípade by stačilo poukázat' na to, že napríklad taký pes alebo 
vysvetlit’ ani to, čo my chápeme ako uhlík, vodík či kyslík. Preto by som uvedený citát poopravil a povedal, že vedecký opis reprezentuje pomery vo svete iba natol'ko, že by sme sa o jeho detailoch mohli zhodnút nanajvýš s bytostami, ktoré by nám boli vel’mi podobné, alebo ktoré by disponovali poznávacími zvláštnostami vel’mi podobnými tým našim.

Marvanova posledná veta pred epilógom zohl'adňuje typ kritiky, ktorú som sa tu snažil predstavit'. Tvrdí:

„Jsme s to dosáhnout jen částečného zmapování nezávislé skutečnosti pomocí našich metod, pojmových schémat a teorií. Je to však skutečné mapování - mapování toho jediného světa, který existuje.“6o

S druhou častou tohto tvrdenia nemám vel'ký problém. Kto by chcel tvrdit', že svet naozaj v našich teóriách tvoríme, musel by byt’ schopný presvedčivo ukázat', ako by to bolo možné. Avšak už použitím slova „mapovat", sa ukazuje, že určitým spôsobom tvoríme štruktúru, skrz ktorú si svet akosi sprostredkovávame. Mapa nepredstavuje fotorealistické zachytenie predlohy. Mapa zohl'adňuje vždy určitý aspekt a napriek tomu, že ide o mapovanie niečoho skutočného, táto mapa je tvorená pre nás, nami a nám zrozumitel’ným spôsobom.

Tým sa však ukazuje, že jadro problému môže byt’ v tom, ako vlastne chápat’ pojem objektivity. Ak je moja kritika platná, tak pohlad bez perspektívy je viac menej nemožný. Ak však nie je možný ani pohl'ad božieho oka, ani pohl'ad z každej možnej perspektívy, čo potom bude náplňou tohto pojmu? Myslím si, že pojem objektivity je možné dosiahnut' tak, že si uvedomíme povahu vedeckej praxe. Veda prináša teórie, ktorých platnost’ sa overuje falzifikáciou. Stanovená hypotéza sa overuje viacerými tímami na viacerých pracoviskách, a ak k rovnakým záverom dospejú všetci zúčastnení, je možné hovorit’ o zhode. Teda pojem objektivity je možné dosiahnut’ odvodením od intersubjektívnej zhody vedenej presnou vedeckou metodológiou.

prasa má násobne citlivejší čuch než my a pod. Predstava, že je naše vnímanie natol'ko dokonalé, že by bolo schopné uchopit’ svet taký, ako je, mi príde d’aleko absurdnejšia než je bytost', ktorú som použil ako príklad.

6o Marvan (2014, s. 125). 


\subsection{Realizmus, veda a "common sense“}

Argumentácia v prospech $\mathrm{R}_{\mathrm{M}}$ jev závere knihy podporená pomocou dvoch tvrdení. ${ }^{61}$ Prvým z nich je presvedčenie, že moderná veda je zlučitel’ná s realistickým stanoviskom. Tento prístup sa už ukázal v predchádzajúcej podkapitole. Peregrin však túto myšlienku problematizuje. Hovorí, že ak by sme mali plne a doslova brat to, čo tvrdí veda, tak všetko, čo existuje je výsledok chvenia super strún, ktoré nijako nedokážeme pozorovat. ${ }^{62} \mathrm{Z}$ toho však vyplýva, že čokol'vek, čo považujeme za svet, je v skutočnosti až dodatočným výsledkom interakcie nášho vnímania s nami zachytených (či už pozorovatel'ných alebo nepozorovatel'ných) entít. Ak potom nechceme skončit pri tom, že svet, taký aký skutočne je, je nám v celku nedostupný, musíme pripustit, že do značnej miery dávame svetu nám známu podobu. ${ }^{63}$ To však neznamená, že ho tvoríme ex nihilo, na základe našej l’ubovôle, tvrdí sa tým to, že naše poznávanie nie je čisté a dokonalé zrkadlo. Metaforicky povedané, ide skôr o rybársku siet' s určitou vel'kostou ôk, ktoré niektorým rybám dovolia prepadnút' a niektorým nie. Avšak na základe toho, že pomocou tejto siete chytáme iba „vel'ké ryby“, nemôžeme povedat', že v mori sú iba tieto ryby.

$\mathrm{K}$ tomu, čo hovorí Peregrin, je možné pripojit aj slová jedného z najznámejších súčasných vedcov a popularizátorov vedy S. Hawkinga. Vo svojej knihe Vel'ký plán, napísanej spolu s L. Mlodinowom hovoria jednu pozoruhodnú vec. Filozofiu ako disciplínu schopnú zodpovedat’ otázky pýtajúce sa na povahu sveta považujú za mŕtvu. ${ }^{64} \mathrm{Na}$ jej miesto podla nich nastupuje moderná veda vo forme modernej fyziky. ${ }^{65}$ Do určitej miery by táto myšlienka podporovala Marvanove presvedčenie o hladkom prepojení vedy s $\mathrm{R}_{\mathrm{M}}$ Avšak na rozdiel od Marvana, ktorý chce hájit’ nezávislú existenciu aj takých vecí, ako sú predmety každodennej

61 Pozri tamže, s. 127.

62 Pozri Peregrin (2014, s. 72).

63 Porovnaj tamže.

64 K tejto myšlienke sa vyjadril Róbert Maco vo svojom článku Filozofia je mŕtva. Nech žije fyzika! (2018). V texte ukazuje, že koncept modelovo závislého realizmu sa napriek snahe autorov neoslobodzuje zo sporu realizmu a anti-realizmu vo filozofii vedy. Na rovnakú knihu napísal recenziu Peter Zamarovský (2013) a vo svojej správe s názvom Je filosofie „mrtvá“? (2011) Jaroslav Peregrin stručne zhrnul rôzne reakcie na Hawkingove myšlienky.

65 Pozri Hawking (2011, s. 13). 
skúsenosti, Hawking poukazuje na to, že veda túto skúsenost'd’alekosiahlo prekračuje a ukazuje obraz v rozpore s touto skúsenostou. ${ }^{66}$ Veda podl'a Hawkinga síce operuje s určitou podobou realizmu, no nakol'ko je tento realizmus zlučitel'ný $\mathrm{s} \mathrm{R}_{\mathrm{M}}$ je otázne.

Hawking hovorí o tzv. modelovo závislom realizme. Teda to, čo v nejakej teórii budeme pokladat' za „skutočné“, bude závisiet’ na stanovenom modeli. ${ }^{67} \mathrm{~A}$ samotný model sa stanovuje skrz rôzne teórie a experimenty. Ak tento model bude zodpovedat' všetkým doterajším pokusom a výsledkom pokusov, môžeme dočasne veci týmto modelom stanovované považovat' za reálne existujúce. ${ }^{68} \mathrm{R}_{\mathrm{M}}$ chce byt' obhajobou nezávislej existencie inherentne štruktúrovanej reality, zatial' čo modelovo závislý (R) hovorí o pripisovaní reálnosti na základe funkčnosti modelu. Teda to, čo tento typ (R) bude chápat' ako reálne, bude závisiet’ na funkčnosti modelu a nie na priamej korešpondencii so svetom.

Ďalší argument $\mathrm{v}$ prospech kladného vzțahu $\mathrm{R}_{\mathrm{M}}$ a vedy je predstava, že vedy fungujú $\mathrm{v}$ akejsi koherencii. Teda pre podporu pravdivosti nejakej teórie hrá fakt, že si jednotlivé disciplíny v rámci zásadných čŕt tejto teórie neodporujú, alebo si jednotlivé teórie daných disciplín neodporujú. ${ }^{69} \mathrm{~V}$ tom nevidím žiaden problém, avšak takáto predstava má pre $\mathrm{R}_{\mathrm{M}}$ jeden problém. Peregrin ho vyjadruje úplne presne:

„Já $\mathrm{s}$ tím problém nemám, ale nechápu, jak by takový argument mohl přijmout Marvan. Realista jako on, zdá se mi, může brát fakt, že je teorie ve shodě s jinými přijímanými teoriemi, za důvod pro přijetí této teorie jedině tehdy, když bude vědět, že ony jiné teorie postihuji věci tak, jak skutečně, nezávisle na nich, jsou. Spočívá-li totiž podle realisty správnost teorie v tom, že postihuje věci tak, jak skutečně, nezávisle na ní, jsou, pak prostá koherence s jinými teoriemi ve prospěch její správnosti nehovoří. " ${ }^{\circ}$

66 Porovnaj tamže, s. 15.

67 Porovnaj tamže.

68 Tamže, s. 15 .

69 Porovnaj Marvan (2015, s. 102).

70 Peregrin (2016, s. 122). 
Ani modelovo závislý realizmus netvrdí, že niektorá z teórií musí korešpondovat’ priamo so skutočnostou, hovorí len to, či vyvracia, podporuje, alebo len neodporuje stanovenému modelu. Peregrin potom naráža aj na to, čo som už prízvukoval vyššie, že $\mathrm{R}_{\mathrm{M}}$ stojí a padá na korešpondencii so svetom, a teda koherencia teórií nie je pre neho arbitrom pravdivosti. Ak má byt’ napr. súlad evolučnej teórie $s(R)$ dôkazom pre platnost' $\mathrm{R}_{\mathrm{M}}$, tak $\mathrm{R}_{\mathrm{M}}$ musí predpokladat', že evolučná teória priamo pomenováva nezávislú realitu. Tu však nastáva jeden problém v argumentácii. Ak má byt’ predpoklad dôkazom predpokladu, ide o kruh, predpokladá sa to, čo sa má dokázat'. Samotná koherencia evolučnej teórie s (R), bez predpokladu toho, že by evolučná teória zrkadlila nezávislú realitu, nie je platným dôkazom pre $\mathrm{R}_{\mathrm{M}}$. To isté tvrdí aj Peregrin a hovorí, že samotná koherencia vied nie je platným argumentom $\mathrm{v}$ prospech $\mathrm{R}_{\mathrm{M}}{ }^{71}$

Ďalším problémom rozoberanej argumentáciev prospech zlučitel'nosti $\mathrm{R}_{\mathrm{M}} \mathrm{s}$ vedou je aj to, že nie je presne vymedzené, akým spôsobom by mali naše najlepšie teórie odrážat štruktúru sveta. Okrem toho, že sa ukazuje, že tieto teórie sú produktívne vzhl'adom na ich schopnost’ koherentne systematizovat’ naše pozorovania a experimenty, predpovedat' vývin skúmaných modelov, akým spôsobom by mali nad to všetko ešte aj odrážat' štruktúru skutočnosti? ${ }^{72} \mathrm{R}_{\mathrm{M}}$ zdá sa, so sebou nesie predstavu, že tieto naše teórie sú schopné postihnút’ svet tak, ako je. Ak sa tým myslí niečo také, ako Wittgenstenova predstava z Traktátu, že štruktúre našich viet zodpovedá štruktúra faktov, nastáva problém. Zoberme si napríklad teóriu atómu; Peregrinovými slovami:

„Taková teorie tedy třeba říká, že nějaký druh atomu se skládá z nějakých protonů a elektronů. Takže bychom měli očekávat, že kdybychom zkonstruovali nějaké mikroskopy neskonale lepší, než jaké máme dnes, tak bychom v nitru nějaké hmoty dokázali najít ony protony a elektrony, jak se k sobě nějakým způsobem tisknou? Taková představa mi připadá, ve světle toho, co nám kvantová teorie o povaze subatomické reality (její neurčitosti apod.) říká, dokonale absurdní.“73

71 Porovnaj tamže, s. 123.

72 Porovnaj tamže, s. 125.

73 Tamže, s. 125 . 
V uvedenom citáte sa ukazuje jedna podstatná vec. Na jednej strane sa predstava atómu a jeho vnútornej štruktúry považuje za platný obraz toho akoje formovaná všetka hmota okolo nás, no na strane druhej, sa pomocou podrobného štúdia subatomárneho sveta ukazuje, že tento obraz atómu je skôr figuratívny a jeho korešpondencia s nejakou nezávislou realitou nie je úplne na mieste. V tomto prípade je efektívnejšie pozerat' sa na atóm ako na model, ktorý na určitej rovine presnosti efektívne opisuje javy zachytávané a pozorované v experimentoch. Vyžadovat’ však, aby tento model nejako presne zodpovedal štruktúre reality je z hladiska d’alších výskumov a prislúchajúcich modelov zbytočné. Toto sa však podobá viac Hawkingovmu modelovo závislému $(\mathrm{R})$ než $\mathrm{R}_{\mathrm{M}}$. Požadovat tak súlad medzi vedou a $\mathrm{R}_{\mathrm{M}}$ je problematické, lebo ani v samotnej vede či vo filozofii vedy ${ }^{74}$ nepanuje zhoda ohl'adom presnej podoby (R), ktorý by bol obhájitel’ný naprieč všetkými teóriami.

Zostáva už len apel na common sense. Charakteristické pre argumentáciu $\mathrm{v}$ prospech $\mathrm{R}_{\mathrm{M}}$ je, že najskôr je stanovená silná téza a následne je oslabená. Nemení sa to ani v tomto prípade a na úvod tohto argumentu Marvan tvrdí, že $\mathrm{R}_{\mathrm{M}}$ je $\mathrm{z}$ pohl'adu zdravého rozumu správnou ontologickou teóriou. ${ }^{75}$ Vzápätí však priznáva, že moderná veda vel’a krát ukázala, že veci sa majú trochu inak, než nám to ukazuje zdravý rozum. Veda prináša rôzne pozorovania, ktoré nás paradoxne nútia opustit’ to, čo nám ukazuje zdravý rozum. Ako príklad je možné použit’ už spomenutú otázku, či sa pri písaní tohto článku hýbem alebo nie. Marvanova odpoved' vo svetle odvolávania sa na common sense ${ }^{76}$ a bežnej skúsenosti môže vyvolat' u čitatel'a rozpačité reakcie. Marvan tvrdí, že spor (R) a (K) nie je možné jednoznačné rozhodnút empirickým testovaním. Tvrdí len, že apel na common sense je symptómom toho,

74 Porovnaj Forbes (2018).

75 Porovnaj Marvan (2014, s. 128).

76 Hoyningen-Huene ku common sense vyjadruje zaujímavú myšlienku. Tvrdí, že rôzne diskurzy sa vedú na rôznych hladinách filozofickej radikality. Zohl'adňujúc, či sa diskurz vedie na úrovni bežnej skúsenosti alebo na úrovni experimentálnej fyziky, bude sa tento diskurz vzd'al'ovat' od common sense a tým narastat na radikalite. Mysliet' si však, že čím bližšie common sense, tým sú argumenty istejšie, môže znamenat nepochopenie diskurzu. Filozofická radikalita vyjadruje to, že diskusia sa vedie vzhl'adom na prehodnocovanie určitých predsudkov prameniacich práve v common sense. Odmietanie diskusie na týchto hladinách radikálnosti môže predstavovat’ odmietnutie filozofie samej. Viac v Hoyningen-Huene (2018). 
že daná filozofická pozícia je v poriadku. ${ }^{77}$ Čo si pod tým predstavit,' zostáva otázkou. Avšak to, že tento spor nie je možné vyriešit empiricky, považujem za protirečenie presvedčeniu, že to, čo vnímame je také aké to je. Predsa empíria, každodenná skúsenost', predstavuje z hl'adiska (R) a v konečnom dôsledku aj $\mathrm{R}_{\mathrm{M}}$, podstatnú evidenciu pre ich platnost'.

Ďalší potencionálny problém so súladom zdravého rozumu a empírie $s R_{M}$ vidím $v$ tom, ako je common sense charakterizovaný. Marvan vychádza z filozofie Thomasa Reida, konkrétne vyberá piaty princíp zdravého rozumu. Uvádza ho nasledovne: „Věci, které rozlišeně vnímáme svými smysly, skutečně existují a skutečně jsou takové, jaké je vnímáme "78 Tento princíp je však na empírii založený. Zdôrazňuje silu nášho vnímania, ktoré je schopné dostat’sa, priamočiaro a neskresl'ujúco, $\mathrm{k}$ veciam samým. Je tak $\mathrm{v}$ súlade $\mathrm{s}$ epistemickým aspektom $\mathrm{R}_{\mathrm{M}}$. Marvan tento princíp pod vplyvom zistení modernej vedy ohladom nášho kognitívneho aparátu modifikuje nasledovne: „Rozlišeně vnímané fyzické věci existují nezávisle na naší mysli a my se pomocí pozorování můžeme dopátrat jejich inherentních vlastností. " ${ }^{9}$ I v tejto modifikovanej verzii zostáva dôraz na empírii, no d’aleko silnejšie je v nej vyjadrený ontologický aspekt, ktorý Marvan v argumentácii zdôrazňuje. Teda dôležité je, že veci existujú nezávisle na nás, naša úloha je podružná. Naše poznanie je potom už závislé len na tom, ako presne sa nám podarí nezávislý, inherentne štruktúrovaný svet zachytit. Čo však považujem za podstatné je, že v oboch prípadoch je empíria dôležitá, no to kontrastuje s tvrdením, že spor (R) a (K) nie je možné rozhodnút empirickým testovaním.

\section{Zhrnutie kritiky}

Mojím zámerom bolo kriticky sa vyrovnat’ s pozíciou Tomáša Marvana, ktorú zastáva vo svojej knihe Realizmus a relativizmus. Túto pozíciu som nazval realizmus marvanovského typu $\mathrm{R}_{\mathrm{M}}$. Ďalej som sa snažil ukázat', že $\mathrm{R}_{\mathrm{M}}$ má dva aspekty, ontologický a epistemický. $\mathrm{Z}$ ontologického

77 Porovnaj Marvan (2014, s. 129).

78 Reid (1852, s. 445) cit. in Marvan (2014, s. 129).

79 Marvan (2014, s. 130). 
hl'adiska je $\mathrm{R}_{\mathrm{M}}$ koncept, ktorý sa hlási nielen k filozofickému, ale aj vedeckému (R). Tým sa hlási nie len ku existencii pozorovatel’ných vecí každodennej skúsenosti a viditel'ných objektov vedy, ale aj ku existencii nepozorovatel'ných entít našich najlepších vedeckých teórií. $\mathrm{Z}$ hl'adiska epistemického aspektu sa $\mathrm{R}_{\mathrm{M}}$ hlási ku presvedčeniu, že veci, ktoré pozorujeme či poznávame cez naše zmysly, náš rozum a rovnako aj pomocou našich najlepších teórií, existujú a existujú tak, ako ich poznávame/vnímame. Implicitne sa tým hovorí, že existuje nám dostupný privilegovaný spôsob prístupu k realite.

V samotnej kritike som sa snažil poukázat’ na nasledovné problémy $\mathrm{v}$ argumentácii $\mathrm{v}$ prospech $\mathrm{R}_{\mathrm{M}}$.

$\mathrm{R}_{\mathrm{M}}$ sa nechce zaväzovat' k nerozumným záväzkom, ako je napríklad korešpondenčná teória pravdy (KTP) či nadčasová ontológia. Avšak samotná argumentácia s týmito konceptami počíta a stojí na nich. Následne na to koncept jedného správneho opisu (JSP) do určitej miery predpokladá KTP a nadčasovú ontológiu. Samotná argumentácia podaná v knihe však z JSP robí triviálny koncept. Potom presvedčenie o možnosti objektívneho stanoviska je spochybnené uvedomením si, že ani veda nie je bez perspektívy.

Na záver, argumentácia v prospech prepojenia $\mathrm{R}_{\mathrm{M}} \mathrm{s}$ modernou vedou je problematická $\mathrm{v}$ tom, že diskusia $\mathrm{z}$ oblasti vedeckého realizmu ${ }^{80}$, ani samotná veda sa nezhoduje na jednej súhrnnej podobe realizmu (R), ktorý by bol neproblematicky zlučitel'ný $\mathrm{s}_{\mathrm{M}}$. Ak je moja kritika akceptovatel'ná, tak $\mathrm{R}_{\mathrm{M}}$ nenapíňa na začiatku stanovenú ambíciu byt' viac, než len minimálnou verziou (R). Nezostáva z neho nič viac, než predpoklad o charaktere reality, teda len základná ontologická téza o existencii nezávislej reality. Zdá sa však, že Marvan presne toto tvrdí:

„... chtěl bych zdůraznit, že realismus, tak jak ho chápu já, Devitt, Searle a další autoři, je ontologická teze. Je to teze o povaze reality. To, zda tuto realitu můžeme poznat tak, jak je, nebo nemůžeme, je z hlediska vymezení realismu druhotné. Klíčové je, zda předpokládáme, že realita má

8o Pozri Forbes (2018). 
strukturu sama o sobě, nebo jestli je její struktura závislá na lidské mysli." ${ }^{11}$

Peregrinova odpoved' na toto tvrdenie vystihuje moje intuície ohl'adom $\mathrm{R}_{\mathrm{M}}$ :

„Toto je ovšem argument, nad kterým mi rozum zůstává skutečně stát. Já se domnívám, že nějakou tezi - at už je to teze o povaze reality nebo čehokoli - přijímáme na základě toho, že poznáme, že je pravdivá. Samozřejmě někdy se může ukázat, že jsme se v tom, že jsme to skutečně poznali, mýlili; ale nedovedu si představit, že bychom nějakou tezi přijímali s tím, že je lhostejné, jestli a jak se můžeme př́slušného poznatku dobrat - tedy v tomto konkrétním př́ípadě jestli a jak můžeme poznat onu realitu, která má údajně sama o sobě strukturu nezávislou na našich teoriích. (Fakt, že Marvan píše, že klíčový je náš předpoklad, že realita má strukturu sama o sobě, se mi pak zdá stavět celé jeho stanovisko na hlavu - nemělo jít o to, že tohle nestačí jen předpokládat, že je třeba to prokázat?)“82

Uvedené Marvanove tvrdenie, považujem za problematické. Samotný predpoklad bez akejkolvek argumentácie v jeho prospech je bezzubý. Ak nie je podstatné to, či dokážeme realitu taká, aká je, poznat', tak môžeme predpokladat čokol'vek. Kantov nepoznatel'ný svet o sebe je od takéhoto predpokladu len tažko odlíšitel'ný. Ak je najdôležitejšie pre vymedzenie realizmu to, že bude predpokladat' existenciu nezávislej reality, tak sa nelíši od minimálnej definície (R) uvedenej na začiatku prvej kapitoly. To je však v rozpore $\mathrm{s}$ Marvanovou ambíciou zastávat špecifickú formu $\mathrm{R}_{\mathrm{M}}$. Nešlo práve o to, dokázat', že (R) je platné stanovisko? Tu teda platí Peregrinove konštatovanie, že obhajovat triviálne koncepty nikam nevedie a tento spor treba opustit. ${ }^{83}$

81 Marvan (2015, s. 98).

82 Peregrin (2016, s. 126).

83 Porovnaj Peregrin (2014, s. 73). 


\section{Spor o akcent a dva argumenty}

Doposial' sa môže zdat', že moja kritika $\mathrm{R}_{\mathrm{M}}$ je vedená z pozície blízkej konštruktivizmu (K), nie je tomu celkom tak. Mojím ciel'om je ukázat' špecifickú verziu realizmu (R), ako efektívnu stratégiu riešiacu rozoberaný spor. To znamená, že v princípe sa s Marvanom zhodujem $\mathrm{v}$ tom, že nechcem redukovat’ svet na beztvaré nič. Predtým však chcem ukázat’, v čom vidím jadro sporu.

Pavol Labuda prináša zaujímavú myšlienku o povahe tohto sporu vo svojom článku Priamočiary realizmus a jeho pozícia $v$ rámci sporu realizmu a antirealizmu. Vychádza hlavne z toho, akú úlohu má v tomto spore jazyk. ${ }^{84}$ Napriek tomu, že Labuda chce zastávat’ priamočiary realizmus $^{85}$ a Kvaszov inštrumentálny realizmus $\mathrm{IR}_{\mathrm{K}}$ považuje za istú variáciu $(\mathrm{K})^{86}$, tak práve $\mathrm{v}$ jeho charakterizácii jadra sporu nachádzam smer, akým je daný spor možné prekonat'.

Jazyk, či užide o každodennú prax komunikácie a koordinovania nášho konania, alebo o vysokošpecializovanú prax vedy, predstavuje nástroj uchopovania, uschovávania a prenášania nášho poznania. Labuda hovorí o neredukovatel'nej pluralite reprezentačných nástrojov komunikácie. ${ }^{87}$ Jazyk, ako nástroj reprezentácie, však reprezentuje viacerými spôsobmi. Reprezentuje tým, že dokáže opisovat'. Nové opisy však dokážu ustanovit’ a zaviest' nové reprezentácie skutočnosti a jej častí. No tým, že jazykom dokážeme niečo opísat' a týmto opisom to aj zastabilizovat’ v jazykovej praxi, dokážeme nastolit’ základy pre d’alšie opisy. Kvasz nazýva tieto funkcie jazyka deskriptívna, konštitutívna a fundačná. ${ }^{88}$ Zo spôsobu akým som tieto funkcie opísal sa ukazuje, že tieto tri funkcie jazyka pracujú nerozlíšene, hoci ich dokážeme dodatočné rozlišovat'. ${ }^{89}$ Podl’a Labudu, jadro sporu leží práve v tom, že jazyk funguje ako nástroj reprezentácie. Potom vzhl'adom na to, aký aspekt reprezentovania je zvýrazňovaný, je možné hovorit’ o realistickom alebo konštruktivistickom stanovisku.

84 Pozri Labuda (2013, s. 64).

85 Pozri tamže.

86 Pozri tamže, s. 71.

87 Pozri tamže, s. 67.

88 Pozri Kvasz (2011, s. 317).

89 Porovnaj Labuda (2013, s. 67). 
„Napätie vzniká medzi chápaním jazyka ako (a) nástroja rozlišovania vo forme zobrazovania rozdielov prítomných v realite a chápaním jazyka ako (b) nástroja konštruujúceho rozlíšenia." 90

Tým, že je jazyk nástrojom reprezentácie, tak nutne je aj nástrojom rozlišovania, lebo tým, že jazyk reprezentuje, tak aj uchopuje a tvorí pre nás funkčné rozlíšenia. Jazyk nám teda pomáha z nepreberného množstva údajov rozoznat' a ustálit jasne uchopitel'né a jednoznačne rozlíšitel'né indivíduá alebo triedy indivíduí. Jadro rozoberaného sporu teda spočíva $v$ reprezentačnej funkcii jazyka, $v$ jeho schopnosti „produkovat“" rozlíšenia. Nezhoda je potom v tom, ako (R) a (K) chápu výraz „produkovat"“. Pre (R) to znamená, že rozlíšenia sú zobrazeniami rozdielov vlastných nezávislej inherentne štruktúrovanej reality. Pre (K) to znamená, že rozlíšenia sú výsledkom jazykovej praxe, a teda indivíduá sa stávajú zrejmými, až po tom, ako sú ustálené jazykovou praxou..$^{91}$ $\mathrm{Z}$ toho potom plynie aj presvedčenie (R) o nezávislosti štruktúrovanej reality a presvedčenie $(\mathrm{K})$ o tom, že skutočnost' je výsledok až následného vloženia štruktúry do „čohosi tam vonku“.

Na základe tejto analýzy rozoberaného sporu sa celá diskusia stáva otázkou akcentu, teda toho kde sa pri argumentácii dáva najväčší dôraz.

„... realisti akcentujú zdroj rozlišovania, ktorým je diferencovaná realita ako existenčno - kauzálny predpoklad pre vývoj rozlišovacej povahy vnímania, myslenia a jazyka. Antirealisti a konštruktivisti akcentujú nutnost’ a unikátnost' procesu rozlišovania, ktorý je jediným percepčným a kognitívnym mostom s realitou a ktorý nachádza svoj výraz v konštitutívnej a fundačnej funkcii jazyka." ${ }^{92}$

Túto čast' považujem za jadro sporu na úrovni všeobecného filozofického diskurzu. Ak sa posunieme do oblasti diskurzu o vedeckom realizme, je

90 Tamže.

91 Porovnaj tamže, s. 67-68.

92 Tamže, s. 77. 
možné doplnit’ spor o akcent sporom o to, ako chápat úspešnost’a platnost’ vedeckých teórií. K tejto téme existuje súhrnné monotematické číslo časopisu Spontaneous Generations: A Journal for the History and Philosophy of Science ${ }^{93}$ mapujúci súčasnú, ale aj načrtávajúci budúcu diskusiu o vedeckom realizme. V úvodnom článku The Future of the Scientific Realism Debate: Contemporary Issues Concerning Scientific Realism je stručne táto debata predstavená. ${ }^{94}$ Napriek tomu, že sa tu rozoberajú rôzne hl'adiská a stanoviská v rámci problematiky vedeckého realizmu, vyberám si dva, pre môj text signifikantné, argumenty. Najednej strane ide o tzv. pesimistickú meta - indukciu PMI a na strane druhej ide o argument žiadnych zázrakov NMA. Platnost’ oboch uvedených argumentov je rôzne spochybňovaná ${ }^{5}$, no pre potreby tohto textu sa sústred'ujem hlavne na všeobecnú charakterizáciu oboch myšlienok. Čo považujem za podstatné je, že oba argumenty vyjadrujú podobné stanoviská ako je tomu v prípade vyššie uvedeného sporu o akcent.

\subsection{Pesimistická meta - indukcia a argument žiadnych zázrakov}

Hlavnú myšlienku PMI je možné vyjadrit’ približne nasledovne; zastávat’ realistický prístup k súčasnému konsenzu ohl'adom pravdivosti či platnosti vedeckých teórií nepredstavuje najspol'ahlivejšiu stratégiu. Historický vývoj poznania jasne ukazuje, že mnoho dobovo presvedčivých a vel'a krát aj produktívnych teórii a predpokladov, ako sú Newtonov predpoklad absolútneho priestoru alebo teória éteru, sa časom ukázali byt' neplatné. ${ }^{96}$ Pesimistická čast' tohto argumentu potom pokračuje indukciou; preto je problematické mysliet’ si, že súčasné teórie sú voči tomuto osudu imúnne.

PMI sa však dá chápat’ dvoma rôznymi spôsobmi, ako na to upozorňuje Arabatzis. ${ }^{97}$ Jeden je zastávaný hlavne Laudanom a na možnost’ druhého upozornil Putnam. V prvom prípade sa argumentácia obracia na historické dôkazy o neplatných a prekonaných, no napriek

93 Forbes (2018).

94 Pozri tamže.

95 Pozri napr. Arabatzis (2018), alebo Hoyningen-Huene (2018).

96 Porovnaj Forbes (2018, s. 6).

97 Pozri Arabatzis (2018, s. 35). 
tomu úspešných teórií. V druhom prípade ide o problém vyvíjajúcich sa konceptov a na základe toho aj často meniacich sa referentov týchto teórií. ${ }^{8} \mathrm{~V}$ oboch prípadoch však problém spočíva v tom, že ontológia, ktorú si so sebou teórie nesú nie je imúnna voči zmene alebo odmietnutiu. Ako však môžu byt’ neplatné teórie úspešné? Pod úspešnostou sa myslí to, že teórie sú schopné vysvetlit’ priebehy a výsledky experimentov a dokážu úspešne predpovedat’ nové javy alebo pozorovania. Prípadne môžu prispiet' k rozvoju nových vedných disciplín.

Ako napríklad skúmanie éteru v devätnástom storočí. Predstava bola taká, že ide o výskum vlastností éteru a jeho interakcie s hmotou. Neskôr sa však ukázalo, že nič také, ako éter neexistuje. Potom ako je možné, že teória budovaná okolo neexistujúcej entity bola schopná rôznych úspešných predpovedí a okrem iného viedla ku vzniku mikrofyziky. ${ }^{99}$ $\mathrm{S}$ touto námietkou sa $\mathrm{v}$ diskusii o vedeckom realizme vyrovnávajú jednotlivé strany rôzne, no čo je pre tento text podstatné je, že PMI vyjadruje práve zdôrazňovanie procesu rozlišovania, o ktorom hovorí Labuda. Teda, tvorbou teórií vkladáme do sveta štruktúru a rôzne modelujeme dostupné dáta a podla potreby ich ontologizujeme. Avšak vplyvom novších poznatkov a nových dát sa stáva, že predchádzajúce modely je potrebné prepracovat’alebo úplne opustit’, lebo nezodpovedajú javom, ktoré sa v experimentoch ukazujú.

Nemyslím si, že samotný argument je dostatočne presvedčivý $\mathrm{k}$ tomu, aby niekto prijal stanovisko o neexistencii inherentne štruktúrovanej reality. Ukazuje však, že naivné (R) stanoviská sú problematické a ohladom ontológie vedy sú neopatrne optimistické. Pesimizmus vyjadrený v PMI tak nie je pesimizmom voči vede alebo poznatel'nosti štruktúry skutočnosti, ale pesimizmom voči trvácnosti a záväznosti modelov, ktoré veda prináša. Povedané laicky, naše súčasné najúspešnejšie vedecké teórie sú to najlepšie, čo máme. To však nie je dôkazom toho, že tieto teórie sú tie najlepšie. Tento argument je tak v súlade $\mathrm{s}$ modelovo závislým realizmom S. Hawkinga, ktorý som opisoval v kapitole 2.4. Rovnako tak je v súlade s uvedomením si, že veda je vysokošpecializovanou intersubjektívnou praxou závislou na nás,

98 Porovnaj tamže, s. 35 .

99 Porovnaj tamže, s. 36. 
našich poznávacích zvláštnostiach a schopnostiach, o ktorých som písal v kapitole 2.3.1.

$\mathrm{Ku}$ úspešnosti vedeckých teórií sa viaže aj druhý argument, tento raz z opačného pólu, a to argument žiadnych zázrakov. V skratke tento argument hovorí, že prediktívna sila vedeckých teórií, či ich úspech pri opisovaní javov a následné technické využitie, ktoré na poznatkoch vedy stojí, by bolo pri najmenšom zázračné, ak by tieto teórie neboli aspoň aproximatívne pravdivé. ${ }^{100}$ Alebo povedané jednoduchšie, ak by prístroj fungoval na základe diametrálne odlišných procesov a mechanizmov, než na základe ktorých bol postavaný, bol by to prinajlepšom zázrak alebo nepredstavitel'ná náhoda. ${ }^{101} \mathrm{~V}$ každom prípade je tento argument $\mathrm{v}$ zhode so spôsobom, akým Marvan argumentoval $\mathrm{v}$ prospech $\mathrm{R}_{\mathrm{M}}$. Podobne aj zdôrazňovanie zdroja rozlišovania, teda diferencovanej skutočnosti, je s týmto argumentom v súlade, lebo, ak je teória budovaná na základe kauzálne pôsobiacej reality, tak aj všetko, čo bude táto teória schopná predikovat’ a previest' do praxe, bude fungovat' v zhode $\mathrm{s}$ touto diferencovanou realitou. Samozrejme aj tento argument je spochybňovaný ${ }^{102}$, no pre tento text je podstatný z hl'adiska špecifikovania zdroju rozoberaného sporu.

Ak je moja analýza správna, tak zdroj sporu (R) a (K) tkvie v tom, aký dôraz je kladený na rôzne aspekty reprezentačnej sily jazyka a v tom, ako budeme rozumiet úspešným vedeckým teóriám, ako reprezentáciám vysoko špecializovaného jazyka vedy. To však otvára rôzne otázky. Hlavne však otázku, akým spôsobom je možné z takto definovaného sporu nájst’ východisko. Tu môže padnút’ námietka, že PMI a NMA sa navzájom vylučujú. Ak platí jeden, tak druhý musí byt’ nutne neplatný. Na začiatku som uviedol, že riešením je hybridné stanovisko, ktoré daný spor dokáže prekonat’ tým, že akcentuje aj zdroj aj proces rozlišovania štruktúry a rovnako dokáže prekonat’ vylučujúci charakter vztahu argumentov PMI a NMA.

Chcem teda nasledovat' Kvaszov návrh a pokúsit’ sa ukázat', že rozoberaný konflikt je možné prekonat stanoviskom, ktoré predstavuje 
prienik umierneného realizmu a umierneného antirealizmu. ${ }^{103}$ Za takéto stanovisko považujem inštrumentálny realizmus L. Kvasza. Práve $\mathrm{IR}_{\mathrm{K}}$ je možné chápat' ako efektívnu stratégiu, ktorá je schopná akcentovat’ ako zdroj, tak aj proces rozlišovania štruktúry vo svete a rovnako dokáže neutralizovat’ vylučujúci vzt’ah PMI a NMA. To sa ukazuje v klúčových myšlienkach $\mathrm{IR}_{\mathrm{K}}$, ako sú inštrumentálne sprostredkované poznanie, špecifický charakter inštrumentov a ontológia rozlíšení, o ktorých budem hovorit’ v nesledujúcich častiach práce. Pokúsim sa teda $\mathrm{IR}_{\mathrm{K}}$ predstavit’ ako rámec, z hl'adiska ktorého je možné nájst' východisko z debaty, ktorá prebehla medzi Marvanom a Peregrinom.

\section{Prekonanie sporu}

Napriek kritickému tónu doterajšieho textu, s Marvanom zdiel'am presvedčenie, že určitý typ (R) je v konečnom dôsledku obhájitel'ný koncept, ktorý nevyústi $\mathrm{v}$ absurdné alebo neprijatel'né dôsledky. Je prirodzenejšie predpokladat', že žijeme v skutočnom svete, ktorý na nás kauzálne vplýva, pričom naše každodenné, ale aj vedecké poznanie sa týka tohto sveta a nie nejakej snovej ilúzie. Avšak problém vzniká vtedy, ked' sa snažíme pochopit’ konkrétnej podobe nášho vztahu s týmto svetom. Ako som to spomínal v predchádzajúcich častiach práce, za zdroj uvedeného sporu považujem zdôrazňovanie zdroja rozlišovania na strane (R), s čím sa prirodzene spája námietka NMA, a na strane druhej tu ide o zdôrazňovanie procesu rozlišovania štruktúry sveta, $\mathrm{s}$ čím sa prirodzene spája argument PMI. Zo spôsobu akým som pristupoval $\mathrm{k}$ Marvanovmu textu je zjavné, že celá uvedená kritika stanoviska $\mathrm{R}_{\mathrm{M}}$ je vedená hlavne $\mathrm{z}$ hl'adiska zdôrazňovania procesu rozlišovania štruktúry sveta a teda aj z hl'adiska PMI. No stanovisko, ktoré chcem obhajovat'nieje úplne stotožnitel'né s (K). Moja kritika mala túto formu hlavne preto, aby sa čo najjasnejšie ukázali problémy (R), ktorý predpokladá priamočiary prístup k realite. Rovnako som chcel touto kritikou čo najviac zvýraznit’ kontrast opozičných stanovísk, čím som chcel opodstatnit moje tvrdenie o tom, v čom spočíva jadro sporu. Napriek zjavne vylučujúcemu vztahu PMI a NMA som presvedčený, že oba argumenty sú opodstatnené, čo 
však prináša problém. Mojím ciel’om je preto ukázat’, že daný spor je možné prekonat’ pomocou stanoviska, ktoré dokáže akcentovat’ obe hl'adiská. Potom ak moja kritika predstavuje vyhranenie sa ku (K), tak nasledujúce odseky predstavujú cestu v ústrety (R).

Zuvedenej kritikyvyplýva viacero otázok, pričom práve charakterizácia $\mathrm{IR}_{\mathrm{K}}$, ako stanoviska, ktoré môže prekonat' rozoberaný spor, predstavuje rozpracovanie odpovedí na tieto otázky. Najzávažnejšie z nich sú tieto:
A. Existuje privilegovaný prístup ku realite?
B. Ako overíme pravdivost' našich teórií?
C. Je možné svet opísat' plne a objektívne?
D. Je možná nadčasová ontológia?
E. Ako vysvetlit’ reprezentačnú silu jazyka?
F. Ako vysvetlit úspešnost' vedeckých teórií?
G. Ako prekonat’ slepú uličku sporu (R) a (K)?

Komplexne charakterizovat $\mathrm{IR}_{\mathrm{K}}$ by si vyžadovalo samostatný článok venovaný len tomuto problému, preto treba považovat túto analýzu za zjednodušujúcu.

Podobne ako Marvan, aj Kvasz sa prihlasuje k presvedčeniu, že existuje na nás nezávislá a inherentne štruktúrovaná realita. ${ }^{104}$ Avšak na rozdiel od Marvana, vztah $k$ tejto realite nie je $v$ prípade $I_{K}$ tak jednoznačný a priamočiary. Kvasz rozlišuje tri pojmy reality subjektívnu, intersubjektívnu a objektívnu. ${ }^{105}$

Subjektívny pojem reality zahŕňa všetko, čo je jedinečné a neopakovatel'né a prináleží jednému konkrétnemu subjektu. Je možné povedat', že táto realita je tá, v ktorej každý individuálne žijeme, obsahuje všetky naše jedinečné zážitky, predstavy, postoje, názory, spôsoby, ako si veci vysvetlujeme. Táto realita je neprenosná a je výsostne viazaná na indivíduum, je to realita subjektívneho prežívania.

Intersubjektívny pojem reality predstavuje svet všetkého, čo je medzi l’ud’mi zdielané. Kultúra, veda a rôzne iné spoločenskovedné praxe. $\mathrm{V}$ tejto rovine sa učíme spoločným poznatkom o svete,

104 Pozri Kvasz (2015a, s. 110).

105 Pozri tamže, s. 110-111. 
spoločným predstavám, spoločným systémom hovorenia o svete a jeho rôznym spôsobom zachytávania. Pre $\mathrm{IR}_{\mathrm{K}}$ je práve tento pojem reality jediný, o ktorom môžeme viest' priame diskusie, a na ktorý sa vztahujú naše vedecké teórie. Je epistemicky relevantný. Dôležitú úlohu tu zohrávajú vedecké a matematické inštrumenty. Tieto nástroje nám sprostredkovávajú realitu. $\mathrm{V}$ prenesenom zmysle slova sú potom podobnými nástrojmi aj naše zmysly.

Potom objektívny pojem reality je z hladiska $\mathrm{IR}_{\mathrm{K}}$ menej dôležitý. To neznamená, že je zbytočný, znamená to, že svet nespoznávame priamo ale sprostredkovane. V momente, ked' nám nástroje sprostredkovávajú nejaký fragment tejto reality prenášajú ju do intersubjektívnej sféry. $\mathrm{Na}$ základe toho, že s každým novším nástrojom sa ukazuje predchádzajúca inštrumentálne sprostredkovanáštruktúra zložitejšia,je možnénepriamo odkazovat' na objektívnu realitu, ako neredukovatel'ne štruktúrovanú. Inak povedané na základe faktu, že nech sa na svet pozeráme čímkolvek a kdekol'vek, vždy narazíme na nejakú štruktúru, môžeme opodstatnene zastávat' presvedčenie, že realita je inherentne neredukovatel'ne štruktúrovaná. Podstatné si je však uvedomit', akú úlohu v tom zohrávajú inštrumenty.

Teda na rozdiel od $\mathrm{R}_{\mathrm{M}}$, kde sa zdá, že máme k realite bezproblémový a priamočiary prístup, na základe čoho potom Marvan môže tvrdit, že veci existujú nezávisle na nás a sú také, ako ich vnímame, $\mathrm{IR}_{\mathrm{K}} \mathrm{si}$ uvedomuje, že nič také, ako priamočiary a bezproblémový prístup k realite nemáme. To však neznamená, že o inherentnej štruktúre reality nemôžeme nikdy nič vediet'. Avšak vzhl'adom na vyššie uvedenú vetu, kde tvrdím, že sa Kvasz prihlasuje k presvedčeniu o existencii nezávislej reality, môže padnút odôvodnená námietka, ako toto presvedčenie zosúladit’ s nemožnostou priamočiaro $\mathrm{k}$ tejto skutočnosti pristupovat'. $\mathrm{Na}$ to Kvasz odpovedá viacerými spôsobmi. Na jednom mieste hovorí, že jeden z dôvodov, ktorý ho presvedčil o existencii štruktúrovanej reality bolo prežitie anafylaktického šoku. Tu si uvedomil, že absolútne nezáleží na tom aké presvedčenia človek zastáva, je tu fakt reality, ktorý kauzálne pôsobí na subjekt. ${ }^{106} \mathrm{~V}$ podobnom duchu sa nesie aj príklad s nárazom motocyklistu na strom. Nezáležiac na tom, aké procesy sú zodpovedné za

106 Pozri Kvasz (2015b, s. 43). 
to, ako daný človek vníma svet, geometrická štruktúra realityjednoznačne vypína všetko konštruovanie, ked’ sila spôsobená náhlym nárazom na relatívne nehybný strom deformuje lebku. ${ }^{107}$ Teda popieranie nezávislej reality je v protiklade so skúsenostou každého s nás. No ked' sa v prípade $\mathrm{IR}_{\mathrm{K}}$ hovorí o nemožnosti k tejto realite priamočiaro pristupovat', nemyslí sa tým, že sme od reality úplne odstrihnutý, myslí sa tým to, že procesy a štruktúry, ktoré na nás pôsobia nám nie sú priamo dostupné. Zmysly nás v prípade anafylaktického šoku informujú pomocou bolesti a iných príznakov o tom, že sa niečo deje, ale epistemicky nám nie je priamo prístupné, ako sa to deje.

Teda podl’a $\mathrm{IR}_{\mathrm{K}} \mathrm{ku}$ svetu pristupujeme vždy už sprostredkovane, skrz rôzne inštrumentálne praxe, kde sa počíta aj zmyslová skúsenosté. A každý inštrument svojou povahou podstatným spôsobom spoluurčuje to, čo nám sprostredkováva. ${ }^{108}$ Už len taký zrak zachytáva len vel'mi chudobné a obmedzené spektrum viditel'ného svetla na bohatej frekvenčnej škále. Prípadne zrak je svojou konštrukciou obmedzený, čo sa týka rozoznávania detailov do dial'ky či na blízko. Zrak nám preto sprostredkováva len úzko vymedzený a značne zahmlený obraz sveta. Čo sa týka vedeckých inštrumentov bude to v ich prípade vel'mi podobné, realitu nám sprostredkovávajú do takej miery, ako im to dovolí ich rozlišovacia schopnost'. Rozlišovacia schopnost’ inštrumentov je daná ich špecifickými obmedzeniami. Napriek tomu, že Kvasz tieto obmedzenia ilustruje hlavne na matematických inštrumentoch ${ }^{109}$, je možné pripísat' tieto medze všeobecne všetkým inštrumentom. Kvasz hovorí hlavne o tom, že inštrumenty sú obmedzené z hl'adiska rozsahu toho, čo a ako dokážu zachytit’. V prípade matematiky hovorí o logických a expresívnych medziach. ${ }^{110}$ Ide o obmedzenia z hl'adiska toho, čo je daným nástrojom dokázatel'né (logické medze) ${ }^{111}$ a z hl'adiska toho, čo je daným nástrojom

107 Porovnaj tamže, s. 211.

108 Pozri Kvasz (2015a, s. 119-120).

109 Pozri Kvasz (2015b, s. 75-76).

110 Pozri tamže, s. 77.

111 Teda poznatok ku ktorému sme sa dostali pomocou jedného inštrumentária, nie je možné dokázat pomocou predchádzajúceho. Kvasz v tomto prípade hovorí: „Príkladom logických medzi jazyka je nedokázatel’nost' základnej vety algebry prostriedkami algebry (bez predpokladu spojitosti číselného oboru)“ Kvasz (2015b, s. 77). 
vyjadritel'ne (expresívne medze) ${ }^{112}$. Zo všeobecného hl'adiska je potom možné povedat', že charakter a vlastnosti každého inštrumentu stanovujú medze tomu, akú čast’ reality pomocou neho poznáme. Každý nástroj si tak nesie určitú rozlišovaciu schopnost', ktorá je objektívne daná samotným nástrojom.

Teda napríklad „lupa umožní stabilným a reprodukovatel'ným spôsobom rozlíšit dva body, ktoré vol’nému pohl'adu splývajú, mikroskop umožní rozlíšit body, ktoré splývajú pri pohl'ade cez lupu, etc.“113

Preto odpoved' na námietku, ako zosúladit’ presvedčenie o existencii nezávislej reality $\mathrm{s}$ tvrdením, že $\mathrm{k}$ tejto realite nemáme priamočiary prístup, bude zniet’ nasledovne. To, že svet spoznávame pomocou obmedzených nástrojov neznamená, že o ňom nič nevieme. Tak isto to neznamená, že túto realitu nemáme ako dokázat'. Práve naopak, aj napriek obmedzenosti inštrumentov vieme o realite toho vel'a, a práve vd’aka tomu, že každý inštrument nám sprostredkováva špecifickú štruktúru, je viac než odôvodnené presvedčenie, že objektívna realita existuje a je neredukovatel'ne štruktúrovaná. Čo je však podstatné na prístupe $\mathrm{IR}_{\mathrm{K}}$ je to, že spochybňuje možnost’ stotožňovania výsledného obrazu získaného skrz inštrumentálne praxe s úplným obrazom o celku reality.

Aby sa však $\mathrm{IR}_{\mathrm{K}}$ vyhol námietke, že takto chápané inštrumenty svet neodhal'ujú, ale ho v podstate vytvárajú, ukazuje, že inštrumenty podstatným spôsobom prináležia realite rovnako, ako veci, na ktoré sa skrz dané inštrumenty zameriavame. ${ }^{114}$ Vedecké inštrumenty externe a kauzálne pôsobia na naše vnímanie rovnako, ako kamene či stromy. Námietka potom môže padnút, že samotné zmysly nemôžu byt’ inštrumentami v tomto zmysle. Ked’ si však uvedomíme, že výsledný „obraz“ skúmaného sa tvorí až v mozgu na základe elektrických impulzov posielaných po nervových dráhach zo zmyslových receptorov, tak je možné s trochou zovšeobecnenia konštatovat', že zmysly sú inštrumentami mozgu rovnako, ako

112 Nejde o našu neschopnost’ pomocou daného nástroju niečo zobrazit’. Ide skôr o to, že pomocou daného nástroja sú zobrazitel'né iba určité veci, potom logicky niektoré sú ním nezobrazitel’né. Podl’a Kvasza je v prípade matematiky toho „ Príkladom ... neriešitel’nost' rovníc piateho stupňa prostriedkami algebry." Kvasz (2015b, s. 77).

113 Kvasz (2015b, s. 116).

114 Porovnaj Kvasz (2015a, s. 109). 
sú d’alekohl'ady či mikroskopy inštrumentami našich zmyslov. ${ }^{115}$ Všetky predchádzajúce odseky je možné považovat' za rozpracovanie otázky $\mathrm{A}$, a čiastočne aj C, E, a G.

$\mathrm{Z}$ tejto špecifickej funkcie inštrumentov vyplýva aj to, že $\mathrm{IR}_{\mathrm{K}}$ odmieta klasickú korešpondenčnú teóriu pravdy. Teda odmieta predstavu, že naším pravdivým teóriám a vetám musí zodpovedat nejaká neteoretická nepojmová a priamo prístupná realita. $\mathrm{IR}_{\mathrm{K}}$ nahrádza tento vztahah korešpondenciou tzv. ontologického jazyka s teoretickým jazykom. Teda $\mathrm{IR}_{\mathrm{K}}$ neporovnáva teóriu priamo so svetom, ale svet inštrumentálnej praxe, ktorej jazyk môžeme dočasne považovat' za ontologický platný s inou inštrumentálnou praxou, ktorej jazyk prináša určité nové alebo rozdielne teoretické vysvetlenia. ${ }^{116}$ Teda stratou priamočiareho prístupu ku svetu strácame možnost’ priameho overenia teórie so svetom. Overovat môžeme koherenciu jedného inštrumentária s iným. Na tomto mieste treba pripomenút', že ak hovorím o strate priamočiareho prístupu $\mathrm{k}$ svetu, netreba si to zamieňat' so stratou akéhokol'vek prístupu k svetu. Ak platí, že inštrumenty majú obmedzené rozlišovacie schopnosti, tak štruktúra, ktorú pomocou nich poznávame nepredstavuje dokonalý obraz reality, ide o obraz daný vzhl'adom na proces, skrz ktorý sme sa $\mathrm{k}$ danému obrazu dostali. Teda ak sa $\mathrm{v} \mathrm{IR}_{\mathrm{K}}$ hovorí o nemožnosti priamočiareho prístupu, tak negovaný nie je kontakt s realitou ale práve priamočiarost' tohto kontaktu. Povedané metaforicky, tvrdit', že svet je taký ako ho poznávame je vyrozprávanie príbehu len do polovice. Tento odsek je možné považovat' za rozpracovanie otázky B, a čiastočne aj D a E.

$\mathrm{Z}$ uvedeného potom vyplýva aj d’alší aspekt $\mathrm{IR}_{\mathrm{K}}$. Naše súčasné a najlepšie opisy sveta nemusia byt’ nevyhnutné, jediné a správne. $I_{\mathrm{K}}$ tak do určitej miery opúšta predstavu, že by sme boli schopní opísat' celý svet. Vzhl'adom na to, že inštrumenty zohrávajú podstatnú úlohu pri opisovaní sveta je neopodstatnené domnievat' sa, že by sme mali jediné správne opisy. V budúcnosti sa môžu objavit’ novšie inštrumenty ${ }^{117}$, ktoré nám ukážu, že štruktúra ktorú sme považovali za platnú a funkčnú je

115 Pozri tamže, s. 117-118.

116 Pozri Kvasz (2011, s. 314).

117 To však neplatí pre zmysly, iba ak by sme boli schopný časom človeka vylepšovat’ pomocou bionických implantátov. 
nedostatočná či príliš redukujúca. Preto $\mathrm{IR}_{\mathrm{K}}$ prináša predstavu, že všetky naše poznatky o svete predstavujú súhrn rôznych máp. ${ }^{118}$ Každá vznikala v rôznom období, s rôznou presnostou ${ }^{119}$ a za rôznym účelom. Niektoré mapy sa prekrývajú, niektoré mapujú úplne iné oblasti a niektoré sa na rovnakú oblast’ pozerajú z viacerých aspektov. Avšak povaha máp je taká, že nereprezentujú úplne presne, ale deformujú, vynechávajú, zvýrazňujú či odhliadajú. Nie je možné súčasne sa pozerat na prednú a zadnú stranu sféry (Zeme). Prekreslením jej plášta síce získavame mapu celej sféry, ale týmto prekreslením sa stáva značne zdeformovaná. Tento odsek je možné považovat’ za čiastočné rozpracovanie otázky $\mathrm{C}, \mathrm{D}$ a F.

Potom na základe odmietnutia epistemickej relevantnosti objektívneho pojmu reality a špecifického charakteru inštrumentov $\mathrm{IR}_{\mathrm{K}}$ problematizuje možnost' objektívneho pohl'adu na vec. Objektívne stanovisko si implicitne vyžaduje privilegovaný prístup k realite, avšak, ak k realite pristupujeme vždy sprostredkovane, privilegovaný prístup sa vytráca. Každá teória prináša špecifické stanovisko či perspektívu, danú inštrumentálnou praxou. Dosiahnut objektívne stanovisko sa dá iba relatívne a to tak, že v prípade súperenia zdanlivo vylučujúcich sa teórii pristúpime na vyšší rámec, ktorý dokáže tieto teórie zjednotit. ${ }^{120}$ Napr. jeden typ inštrumentálnej praxe špecifikuje svetlo ako majúce časticový charakter. Dokonca to dokáže pomocou experimentov. Iný typ praxe zas chápe svetlo ako vlnenie a taktiež má svoje dôkazy. Na vysvetlenie tohto sporu sa časom vytvoril širší rámec, ktorý dokázal vysvetlit’ svetlo ako vlnovo - časticové. To znamená, že rôzne praxe dokážu priniest’ rôzne jemné rozlíšenia, avšak je tažké tvrdit’, že by sme sa tým dostávali do pohl'adu mimo špecifickú perspektívu. Tento odsek je možné považovat' za rozpracovanie otázky C, a čiastočne aj D a F.

$\mathrm{Ku}$ špecifikácii $\mathrm{IR}_{\mathrm{K}}$ by som pridal ešte jeden aspekt. Inštrumentálna povaha nášho prístupu ku skutočnosti má určitý ontologický dôsledok. Kvasz zastáva názor, že d’aleko vhodnejšia ontológia, než je klasická ontológia substancií (Kvasz ju nazýva ontológia výplní), je ontológia

118 Pozri Kvasz (2015b, s. 56-57).

119 Teda pomocou nástrojov s rôznou rozlišovacou schopnostou.

120 Pozri Kvasz (2015a, s. 115-116). 
rozlíšení. ${ }^{121}$ Čo to znamená? Klasická ontológia vyhlasuje za skutočne existujúce veci, ktoré vnímame alebo, ktoré postulujú naše najlepšie teórie.

Tu nastáva však jeden problém, napr. môže sa vyskytnút teória, ktorá sa po určitú dobu zdá platná a stanovuje určité objekty ako reálne existujúce. Avšak vznikom novej inštrumentálnej praxe a tým aj iného či jemnejšieho rozlíšenia sa ukáže, že to, čo predchádzajúca teória považovala za skutočné sa rozplynie. Príkladom môže byt historická teória vysvetl'ujúca šírenie tepla, teória kalorika. Kalorikum sa pokladalo za špecifický druh substancie, ktorá sa na základe hydrodynamiky tekutín prelievala z telesa do telesa, čím sa vysvetl'ovalo chladnutie a zohrievanie telies. Existovala rovnica, ktorá tento jav opisovala, rovnica vedenia tepla. Neskôr vznikom nových nástrojov sa ukázalo, že nič také, ako kalorikum neexistuje, napriek tomu sa ukázalo, že rovnica vedenia tepla je formálne správna.

Teda sa ukazuje, že zaviazaním sa $\mathrm{k}$ ontológii vecí či výplní, sa vystavujeme riziku, že budeme pokladat’ za reálne veci, ktoré sa v ontológii inej teórie rozplynú. Pozoruhodné na príklade s kalorikom je však to, že rovnica vedenia tepla zostala viac menej platná. Teda Kvasz navrhuje pristúpit na ontológiu rozlíšení, teda za skutočné budeme pokladat rozlíšenia jednotlivých inštrumentálnych praxí. Rozlíšenia, ako akési oká na sieti ktorú vkladáme do sveta. Metaforicky povedané, potom vel'kost' týchto ôk na sieti bude rozhodovat' o tom, čo sa nám v danej sieti zachytí. ${ }^{122}$ Zjemnením tohto rastru alebo jeho zhrubením sa nám určité výplne, alebo „zachytené objekty“ stratia a iné zasa ukážu. Tri predchádzajúce odseky je možné považovat’ za rozpracovanie otázky D a F.

Ak by som mal zhrnút podstatnú myšlienku $\mathrm{IR}_{\mathrm{K}}$ do jednej vety: inštrumentálna prax vkladá do sveta raster, raster zásadným spôsobom určuje, čo sa v ňom zobrazí, avšak toto vkladanie nie je l'ubovol'né, riadi sa charakterom inštrumentov, ktoré zásadným spôsobom prináležia nezávislej inherentne štruktúrovanej realite. Metaforicky povedané, v sieti sa nám zachytávajú iba tie ryby, ktoré neprepadnú cez nami

121 Pozri Kvasz (2015b, s. 48-52).

122 Pozri Kvasz (2015a, s. 130). 
určené oká tejto siete. Dôležité však je, že chytáme ryby a nie predstavy rýb. ${ }^{123}$

V predchádzajúcich odsekoch som sa snažil ukázat’ jednu podstatnú vec. Charakterizovat’ povahu reality a pri tom nebrat’ do úvahy spôsob akým ju poznávame zahal'uje komplexnost’ a váhu toho, že sme vôbec schopní podujat' sa samotného charakterizovania reality.

$\mathrm{IR}_{\mathrm{K}}$ je koncept, ktorý práve ukazuje, že charakterizácia povahy reality je podstatným spôsobom podmienená špecifickostou nášho poznávania. Sprostredkovaný charakter poznania je efektívna stratégia použitel’ná na prekonanie sporu (R) a (K) na úrovni všeobecného filozofického diskurzu, ale aj na úrovni otázok z oblasti vedeckého realizmu. Táto efektívnost' spočíva v tom, že inštrumentálny charakter poznania ukazuje rovnako podstatne zdroj, ale aj proces rozlišovania štruktúry vo svete. Tým, že inštrumenty svojou povahou podstatným spôsobom prináležia nezávislej realite, tak to, čo nám sprostredkovávajú nie je predstavou alebo konštruktom mysle, ale ide o črty a časti inherentne štruktúrovanej reality, ktorá kauzálne na nás skrz dané nástroje pôsobí. Avšak to, že dané inštrumentárium a prax na neho naviazaná nám dokáže niečo o realite povedat' neznamená, že dostávame priamočiari a úplný obraz o danom fenoméne. Obmedzená rozlišovacia schopnost’ nástrojov daná skrz ich logické a expresívne medze, ukazuje, že spôsob akým nám daný nástroj sprostredkováva realitu spolukonštituuje získaný obraz.

Teda skrz proces rozlišovania štruktúry vieme povedat', že zdrojom tohto rozlišovania je daná štruktúra. Tým sa dostávam ku vylučujúcemu vzt’ahu námietok PMI a NMA. Ak prijmeme, že každý typ inštrumentálnej

123 Ukazuje sa, že $I_{K}$ je v niektorých veciach podobný Kantovej epistemológii o vrodených formách nazerania. V skutku je to tak, Kvasz považuje Kanta za objavitel'a sprostredkovaného poznania a $\mathrm{IR}_{\mathrm{K}}$ za Kantove dedičstvo. Kvasz tento prístup k poznaniu charakterizuje ako vzt’ah medzi realitou a jej obrazom vo vedomí. Okrem mnohých problémov, ktoré na tomto prístupe nachádza, je v prípade Kanta to, že vrodené formy nazerania sú subjektívne a k formácii vnemov dochádza v neprístupnej sfére subjektu. Ďalší kto podl’a Kvasza pokračuje v tomto type epistemológie je Putnam, ktorý medzi realitu a jej obraz vo vedomí vkladá pojmové schémy. Výhodou pojmových schém je, že nie sú výhradne subjektívne, ide o jazykovo uchopené a intersubjektívne zdiel'ané presvedčenia a systémy presvedčení. No i tak sú v určitom zmysle nedostatočné, lebo zostáva otázne ich ukotvenie v nezávislej realite. $\mathrm{IR}_{\mathrm{K}}$ je potom tretím pokusom vysvetlit’ vzt’ah medzi realitou a jej obrazom vo vedomí. Inštrumenty a inštrumentálne praxe, ako svojou podstatou fyzické predmety prináležiace nezávislej realite, dokážu pojmové schémy ukotviț v nezávislej realite, to d’alej opisujem v texte. $\mathrm{Ku} \mathrm{IR}_{\mathrm{K}}$ ako dedičstvu Kantovej epitemológie viac v príslušných kapitolách Kvasz (2015a) a Kvasz (2015b). 
praxe nám prináša rozlíšenia s obmedzenou presnostou, tak je možné povedat', že záväznost’ prislúchajúcej ontológie je operatívna. Preto Kvasz navrhuje priklonit’ sa skôr ku ontológii rozlíšení namiesto ontológie výplní, lebo veci, ktoré sa ukazujú na úrovni presnosti jednej inštrumentálnej praxe, sa môžu na úrovni presnosti inej zmenit', alebo dokonca rozplynút'. To však ešte stále nie je úplná odpoved’ na to, ako dokáže $I_{\mathrm{K}}$ vylučujúci vztảa PMI a NMA neutralizovat'. Ak sa vrátim k príkladu s Fourierom a jeho kalorikom, Kvasz k tomu hovorí:
„Ked’že nedokázali dosiahnut’ až na úroveň molekulárnych rozlíšení, postulovaním kalorika jazyk syntakticky uzavreli na makroskopickej úrovni. Vd’aka tomu bolo možné v tomto jazyku počítat', argumentovat’ a odvodit napríklad aj rovnicu vedenia tepla." ${ }^{124}$

Z hl'adiska argumentu PMI je Fourierova teória vedenia tepla exemplárom prekonaného konceptu, pri ktorom by bolo chybou zaväzovat’ sa ku ontológii kalorika. Avšak z hladiska NMA je nanajvýš pozoruhodné, že rovnica, ktorá bola na základe predpokladu existencie kalorika formulovaná, opisuje čast’ termodynamických javov v zásade presne. $Z$ hl'adiska $I_{\mathrm{K}}$ je to vysvetlitel'né tak, že inštrumentárium použité Fourierom a jeho nasledovatel'mi pracovalo na určitej miere presnosti, pričom rozlišovacie schopnosti dobovej výskumnej praxe ukazovali, že za tepelnými javmi stojí špecifická štruktúra, ktorú postulovali ako kalorikum. Syntaktické uzatvorenie jazyka, o ktorom hovorí Kvasz by sa dalo pripodobnit' ku stanoveniu jednej z vlastností modelu skúmaného javu, kde sa pomocou manipulácie s častami modelu skúmajú zákonitosti čŕt reality, ktorých reprezentáciou by mal daný model byt. Potom ak sa zdá, že sa PMI a NMA vylučujú, tak je to spôsobené tým, že výsledné reprezentácie čŕt reality sú stotožňované s finálnym obrazom celkovej skutočnosti.

Prečo to hovorím? Ak budeme zastávat' presvedčenie, že realitu poznávame priamočiaro a neskryto, tak je oprávnené pýtat' sa prečo sa tol'ko mýlime. Na jednej strane môže byt' omyl vysvetlený našou 
nedostatočnostou či nekompetentnostou, teda omyl je našou chybou. To je však v rozpore so základným predpokladom (R), že realitu poznávame priamo, a takto isto je to $\mathrm{v}$ rozpore s tým, že sme $\mathrm{v}$ rôznych sférach poznávania sveta pokročili vcelku d'aleko. Druhá možnost’ako to vysvetlit’ je spolu s Kvaszom pripustit', že svet nepoznávame priamo a neskryto, ale nutne sprostredkovane. V takom prípade bude najdôležitejšie pýtat sa akú povahu má toto sprostredkované poznanie. Potom, ak sú podstatou nášho poznávania inštrumenty a prax s nimi spojená, je možné odôvodnit’ omyl tým, že inštrumenty majú vždy určitú rozlišovaciu schopnost'. Teda, ak inštrumentálne sprostredkované poznanie prináša poznanie obmedzené rozlišovacou schopnostou používaných inštrumentov, tak stotožnit získané reprezentácie čŕt skutočnosti s presným a hotovým opisom reality je predčasné.

Východiskom je ukázat', že ontológie daných reprezentácii majú skôr operatívny charakter, ako súčasti modelov a pre danú rovinu presnosti môžu figurovat’ ako platná reprezentácia skutočnosti, netreba však zabúdat', že táto reprezentácia je viazaná na dané inštrumentárium. Potom ak $\mathrm{IR}_{\mathrm{K}}$ preferuje ontológiu rozlíšení, tak tým hovorí napr. v prípade Fouriera to,
„že nech už si tepelné javy predstavujeme ako tok kalorika, neusporiadaný pohyb molekúl, alebo ako kvantový proces, nutne dostaneme exponenciálny pád teploty, ktorý táto rovnica predpovedá." ${ }^{125}$

Rovnica vedenia tepla, o ktorej tento citát hovorí je potom to rozlíšenie, ktoré opisuje skutočnú črtu reality. Teda $\mathrm{IR}_{\mathrm{K}}$ prekonáva vylučujúci vzt’ah NMA a PMI tým, že silu NMA oslabuje sprostredkovaným poznaním: poznávame realitu nie ilúziu konštruovanú našou mysl'ou, no toto poznanie nie je priamočiare a charakter poznatkov je spolu určený spôsobom poznávania. Silu PMI potom oslabuje tým, že pesimizmus obsiahnutý v tomto argumente nemieri na to, či sme schopní realitu nejak relevantne poznat', ale na záväznost’ ontológii a na stotožňovanie reprezentácii našich teórii s celkovým obrazom skutočnosti. 


\section{Zhrnutie}

Ak je moja kritika $R_{M}$ platná, ukázalo sa $v$ nej, že v podobe $v$ akej je $\mathrm{R}_{\mathrm{M}}$ predstavený, je $\mathrm{v}$ konečnom dôsledku prázdny. Je nejednoznačne vymedzený. Napriek odmietnutiu neudržatel’ných záväzkov, ako sú KTP a nadčasová ontológia s nimi v argumentácii počíta. Koncept JSP sa taktiež ukazuje ako triviálny, lebo argumentácia $\mathrm{v}$ jeho prospech z neho robí nedosiahnutel'ný ideál. Odvolávanie sa na zdravý rozum a súlad $\mathrm{s}$ vedou je problematické hlavne $\mathrm{v}$ tom, že zdravý rozum nestačí na vysvetlenie javov, ktoré sa zdajú byt' $\mathrm{s}$ ním $\mathrm{v}$ rozpore a realistické stanoviská vo vede nezdiel'ajú vel'a podobností $\mathrm{s} \mathrm{R}_{\mathrm{M}}$.

Zdroj sporu (R) a (K) som charakterizoval ako spor o zdroj a proces rozlišovania štruktúry vo svete, a taktiež ako spor o líšiace sa chápanie úspešnosti vedeckých teórií vyjadrené vylučujúcimi sa argumentami NMA a PMI. Ako prekonanie tohto sporu som sa snažil ukázat’ inštrumentálny realizmus L. Kvasza $\mathrm{IR}_{\mathrm{K}}$.

Nazákladecharakterizáciepodstatných čŕt IR ${ }_{\mathrm{K}}$ jemožnépovedat,,žetento koncept akcentuje ako zdroj, tak aj proces rozlišovania, lebo si uvedomuje kauzálnu spojitost’ vonkajšej reality s inštrumentálnou praxou. No tým, že značná čast' inštrumentov je limitovaná svojou rozlišovacou schopnostou, sa ukazuje závažnost' procesu rozlišovania. $\mathrm{IR}_{\mathrm{K}}$ taktiež odpovedá na to, prečo sú úspešné teórie prekonávané. Teórie sú nielen výsledkom, ale aj predpokladom pre rôzne inštrumentálne praxe. Avšak tým, že jednotlivé inštrumenty majú obmedzenú rozlišovaciu schopnost', je možné, že tvorbou nových nástrojov sa ontológie, či „výplne“ dané touto schopnostou stratia alebo zmenia. Teda jedna inštrumentálna prax môže ontológiu tej predchádzajúcej považovat’ za prázdnu, prípadne dokáže ukázat', v čom je nesprávna alebo obmedzená. Potom platnost' ontológií daných pomocou predchádzajúcich rozlíšení je vždy obmedzená vzhl’adom na prax, v ktorej sú používané. Teda $\mathrm{IR}_{\mathrm{K}}$ pomocou sprostredkujúceho charakteru poznania, obmedzenou rozlišovacou schopnostou inštrumentov, preferenciou ontológie rozlíšení pred ontológiou výplní, neutralizuje vylučujúci vztah PMI a NMA. Podstatou tejto neutralizácie je na jednej strane oslabenie NMA poukázaním na sprostredkovaný charakter poznania, teda realitu nepoznávame priamo, ale pomocou obmedzených nástrojov. Na druhej 
strane to je oslabenie pesimizmu argumentu PMI v tom, že sa spochybňuje trvalá záväznost’ontológií získaných skrz rozlíšenia a taktiež sa spochybňuje stotožňovanie získaných obrazov skutočnosti s úplným a presným opisom skutočnosti. Teda $\mathrm{IR}_{\mathrm{K}}$ sa zbavuje radikálnosti predstavy priamočiareho prístupu k realite pomocou PMI a pomocou NMA radikálnej predstavy (K), že štruktúra reality má výlučný pôvod v človeku.

\section{Literatúra}

Alai, M. (2018): „How Deploy Realism withstands Doppelt’s Criticism.“ Spontaneous Generations: A Journal for the History and Philosophy of Science 9 (1): 122-135.

Arabatzis, T. (2018): „Engaging philosophically with the history of science: two challenges for scientific realism." Spontaneous Generations: A Journal for the History and Philosophy of Science 9 (1): 35-37.

Forbes, C. (2018): „The Future of the Scientific Realism Debate:

Contemporary Issues Concerning Scientific Realism.“

Spontaneous Generations: A Journal for the History and Philosophy of Science 9 (1): 1-11.

Hawking, S. \& Mlodinow, L. (2011): Vel'ký Plán. Slovart, Bratislava. Hoyningen-Huene, P. (2018): „Are there good arguments against scientific realism?" In Philosophy of Science, eds. A. Christian, D. Hommen, N. Retzlaff \& G. Schurz, vol. 9, Springer, s. 3-22. Dostupné z: https://doi.org/10.1007/978-3-319-72577-2_1.

Kvasz, L. (2011): „Matematika a skutočnost.'“ Organon F 18 (3): 303-330.

Kvasz, L. (2015a): „Inštrumentálny realizmus - odpoved’ na kritiky.“ Organon F 22 (1): 109-131.

Kvasz, L. (2015b): Inštrumentálny realizmus. Pavel Mervart, Praha. Labuda, P. (2013): „Priamočiary realizmus a jeho pozícia v rámci sporu realizmu a antirealizmu. " Organon $F 20$ (Supplementary Issue 1): 64-78.

Maco, R. (2018): „Filozofia je mŕtva. Nech žije fyzika!“ Filozofia 73 (4): 269-281.

Marvan, T. (2014): Realismus a relativismus. Academia, Praha. 
Marvan, T. (2015): „Lze rožrešit spor mezi realismem

a konstruktivismem?" Filosofie dnes 7 (1): 64-74.

Peregrin, J. (2011): „Je filosofie ,mrtvá'?“ Filosofie dnes 3 (2): 91-93.

Peregrin, J. (2014): „Realismus, relativismus a trápení ducha.“ Filosofie dnes 6 (2): 64-74.

Peregrin, J. (2016): „Tak dobře, trapme ještě chvilku ducha.“ Filosofie dnes 8 (1): 121-127.

Hamilton, W. \& Stewart, D., eds. (1852): The Works of Thomas Reid, D.D. Maclaclan and Stewart, Edinburgh.

Wells, J. D. (2016): In Praise of Theory and Speculation: Essays and Commentaries. [online]. Ann Arbor, Michigan [cit. 10. 2. 2019]. Dostupné na: https://deepblue.lib.umich.edu/bitstream/ handle/2027.42/136201/ipotas.pdf?sequence $=1$ \&isAllowed=y.

Zach, M. (2017): „Vědecký realismus jako kultivace ducha.“ Fïlozofia 72 (5): 381-391.

Zamarovský, P. (2013): „S. Hawking - L. Mlodinow, The Grand Desing." Organon F 20 (1): 125-128.

\begin{abstract}
Is it possible to solve the dispute between realism and constructivism?

The aim of this paper is to engage in a debate on the conflict between realism and constructivism that occurred between Jaroslav Peregrin and Tomáš Marvan, on the pages of journal Filosofie dnes. The discussion developed as a reaction to Marvan's book Realismus a relativismus. In his book, Marvan defends specific kind of realism, criticizing relativistic positions. Peregrin claims that this conflict cannot be resolved, because in the end, both sides are irrefutable and arguments for and against leads to deadlock. On the other hand, Marvan claims that conflict can be resolved in favour of realism. Presented paper defines itself against both claims and proposes solution for the conflict. The solution is to dissolve the conflict using a hybrid concept that can overcome the problems of realism and constructivism. The paper is divided to three main parts. The first part deals with Marvan's realism. The source of the conflict is main topic of second part and last part deals with the concept that can overcome the conflict.
\end{abstract}

Keywords: realism, relativism, constructivism, science, conflict

Kostolný, R. (2019): „Je možné vyriešit spor realizmu a konštruktivizmu?“ Filosofie dnes 11 (1): 50-96. Dostupné z www.filosofiednes.ff.uhk.cz 